\title{
Discourse Analysis of the Communicative Approaches Used by The Pre-service Teachers
}

Esra $\mathrm{UÇAK}^{* a}$, Hüseyin BAĞ ${ }^{\mathrm{b}}$

\section{Article Info}

DOI: $10.14686 /$ buefad.354019

Article History:

Received: $\quad 16.10 .2017$

Accepted: $\quad 15.04 .2018$

Published: $\quad 30.06 .2018$

Keywords:

Science classes,

Communicative approach,

Dialogic instruction.

Article Type:

Research article.

\begin{abstract}
The purpose of the study is to determine the communicative approaches used by pre-service teachers in science teaching. For this purpose, a 7-week training program was developed and applied to raise the pre-service teachers' awareness of dialogic teaching and communicative approach. Before and after this training program, one lesson of each pre-service teacher was video-recorded. These videos were analyzed on the basis of four classes of communicative approach developed by Mortimer and Scott (2003). In line with the purpose of the study, the discourse analysis method was employed to determine the communicative approach used by the pre-service teachers. Moreover, the pre-service teachers were asked to watch their lessons video-recorded before and after the implementation of the training program and to write which communicative approach they used in these lessons and why they used this approach. The findings of the current study revealed that the pre-service teachers mostly preferred the authoritative approach before the training program; yet, after the training program, besides the authoritative approach, they started to use dialogic interaction-based communicative approach in their lessons. Their reasons for using this communicative approach were also elicited.
\end{abstract}

\section{Öğretmen Adaylarının Fen Öğretiminde Kullandıkları İletişimsel Yaklaşımların Söylem Analizi}

\begin{tabular}{|c|c|}
\hline \multicolumn{2}{|c|}{ Makale Bilgisi } \\
\hline \multicolumn{2}{|c|}{ DOI: $10.14686 /$ buefad.354019 } \\
\hline \multicolumn{2}{|c|}{ Makale Geçmişi: } \\
\hline Geliş: & 16.10 .2017 \\
\hline Kabul: & 15.04 .2018 \\
\hline Yayın: & 30.06 .2018 \\
\hline \multicolumn{2}{|c|}{$\begin{array}{l}\text { Anahtar Kelimeler: } \\
\text { Fen dersleri, } \\
\text { İletişimsel yaklaşım, } \\
\text { Diyalojik öğretim. }\end{array}$} \\
\hline $\begin{array}{l}\text { Makale } \\
\text { Arasstırm }\end{array}$ & lakalesi \\
\hline
\end{tabular}

\section{Öz}

Bu çalışmanın amacı, fen bilgisi öğretmen adaylarının fen öğretiminde kullandıkları iletişimsel yaklaşımları belirlemektir. $\mathrm{Bu}$ amaçla, öğretmen adaylarına diyalojik öğretim ve iletişimsel yaklaşıma yönelik farkındalık oluşturmak için 2012-2013 akademik yılının ikinci yarısında öğretmenlik uygulaması dersinde 7 hafta süren bir eğitim programı geliştirilmiş ve uygulanmıştır. Eğitim öncesi ve sonrası öğretmenlerin birer dersleri videoya kaydedilmiştir. Öğretmen adaylarının ders videoları Mortimer ve Scott (2003) tarafından geliştirilen iletişimsel yaklaşımların sınıflarına göre analiz edilmiştir. Araştırmanın amacı doğrusunda öğretmen adaylarının kullandıkları iletişimsel yaklaşımları belirlemek için söylem analizi yöntemi kullanılmıştır. Ayrıca ögretmen adaylarından eğitim öncesi ve sonrası derslerini izlemeleri ve kendilerine göre derslerinde sıklıkla kullandıkları iletişimsel yaklaşımı ve bu iletişimsel yaklaşımı kullanma gerekçelerini yazmaları istenmiştir. Araştırmanın bulgularına göre, çalı̧̧maya katılan öğretmen adaylarının eğitimden önce sıklıkla otoriter yaklaşımları tercih ettikleri, eğitimden sonra ise otoriter yaklaşımların yanında diyalojik etkileşimli iletişimsel yaklaşımı da derslerinde kullanmaya başladıkları tespit edilmiş ve kullanmalarındaki gerekçeler ortaya çıkarılmıştır.

\footnotetext{
*Corresponding Author: esucak0@ gmail.coma

${ }^{a}$ PhD., Pamukkale University, Education Faculty, Denizli/Turkey, http://orcid.org/0000-0003-2897-6462

bProf.Dr., Pamukkale University, Education Faculty, Denizli-Turkey. http://orcid.org/0000-0002-7838-840X
} 


\section{Introduction}

\section{Dialogic Instruction}

Dialogue is seen not only as a process of acquiring ideas and consensus on a particular topic, but also as a process of acquiring knowledge that students have not previously acquired on their own (Game and Metcalfe, 2009: 45). In other words, because of the intense social interaction experienced in the dialogue process, individuals educate themselves and other participants. Dialogue, therefore, has a pedagogical potential. It derives its power from social interaction, which is also the basis of the social constructivist philosophy. Therefore, on the basis of the idea that learning and teaching has a socio-cultural aspect, researchers have used the concept of "dialogic instruction" (Alexander, 2006; Nystrand, Gamoran, Kachur, Prendergast, 1997).

According to Alexander (2006), dialogic instruction should seek ways of expanding the reasoning and conception of the student. In addition, making students active is important in dialogic instruction. Key characteristics of dialogic instruction; collective, opposite, supportive, cumulative and purposeful (Alexander, 2006). The key point in dialogic instruction is that classroom speech should be cumulative in nature. That is, teachers and students develop ideas and in this way jointly construct information in the classroom environment (Mortimer and Scott, 2000). Dialogic instruction is supported by the increasing use of original and subject-relevant questions posed by the teacher. But what really matters here is the nature of the communication surrounding these questions (Nystrand, Wu, Gamorgan, Zeiser and Long, 2003). In general, the most critical thought in dialogic instruction concerns how much active roles are assigned to students as participants in building their own knowledge base in classroom speech (van Zee and Minstrell, 1997; van Zee, Iwasyk, Kurose, Simpson and Wild, 2001). Therefore, the role of teachers is to encourage students to participate actively in class, stimulate ideas and opinions, and support their reasoning, thus helping them to construct their knowledge base (Lehesvuori, 2013).

In dialogic instruction, the students' ideas are considered without being judged, their participation is supported, ideas are discussed and respected. When different stages of inquiry-based instruction are evaluated, the lack of dialogic dimension emerges as a major challenge. This is due to the fact that the inquiry-based research is not conducted as it should because teachers are seen either to control more than what is required in the inquiry; that is, adopt the authoritative approach or to never direct students; which should not happen in the inquiry-based approach. Especially while shifting from simple daily explanations to more scientific ones, the teacher himself/herself should not transmit all scientific knowledge to students in the classroom environment, though this knowledge is needed (Roth, 2005).

Inquiry in dialogic instruction develops high-level thinking (Chin, 2006) and involves appropriate use of different communicative approaches, and therefore brings more meaningful learning activities (Scott and Amettler, 2007). The most important role in initiating and maintaining such activities belongs to the teacher intending to be not only the source of information but also the manager of the in-class communication. Students are not expected to learn without the guidance of the teacher (Roth, 2005). However, if teachers want to carry out the instruction in a meaningful manner, they can adopt meaningful discursive strategies in learning processes (Mercer, Dawes, Wegerif and Sams, 2004).

Dialogic instruction in science classes can be understood not only as a reciprocal interaction between the supporter and participants in the class, but also as the teacher's managing the dialogue between different ideas (e.g. daily and scientific information) (Mortimer and Scott, 2003). An effective science teacher will not only help students understand the content of the science curriculum, but will also help students to better understand science. Therefore, Lemke's (1990) suggestion that "science education should make students people who can speak of science fluently" can be elaborated as "science education should make students speakers who are aware of what they say, thoughtful and can speak fluently" (Mortimer and Scott, 2000).

Dialogic instruction includes important features to promote deeper learning and motivation. However, it has failed to adequately emphasize the fact that science teaching must also have an authoritative dimension. The gap between scholarly knowledge and students' prior knowledge cannot be closed only by using dialogic approaches. That is, students come to classes with their daily information. The aim of the teacher should be to convert the everyday language of students into a scientific language using the communicative approach. But the teacher cannot fulfill this aim only by using dialogic approaches. Authoritative approaches need certainly to be used during the 
lesson. Thus, the concept of communicative approach (Mortimer and Scott, 2003) presents a different perspective to the description of science class interaction, taking into account both the dialogic and the authoritative view.

\section{Interaction in Science Classes}

According to Mortimer and Scott (2003: 24-25), there are patterns in science classes that teachers and students use when interacting with each other. The purpose of creating these patterns is to describe and analyze the ways teachers manage the speech in science classes in such a way as to promote students' learning. To this end, an analytic framework has been developed (Table 1). This framework addresses different aspects of teacher-student interaction in science classes and is a tool for planning and analyzing science teaching interactions. This analytical framework is built on five interconnected dimensions.

Table 1. Analytic Framework: A Tool for Planning and Analyzing Science Teaching Activities
1. Instructional Objectives
2. Content

3. Communicative Approach
4. Patterns of Discourse
5. Teacher Interventions

On the center of the framework is there the concept of "communicative approach" and it brings a viewpoint of how the teacher should work with students to develop ideas in the class. Mortimer and Scott (2003) used the concept of communicative approach to develop students' knowledge in science classes and to qualify how teachers use the language. The classes of communicative approach have been defined on the basis of whether the in-class discourse is authoritative or dialogic in nature and whether it is interactive or non-interactive (Mortimer and Scott, 2003: 33). The classes of communicative approach are shown in Table 2.

Table 2. Classes of Communicative Approach

\begin{tabular}{lll}
\hline & \multicolumn{1}{c}{$\begin{array}{c}\text { INTERACTIVE } \\
\text { Many Voices }\end{array}$} & \multicolumn{1}{c}{$\begin{array}{c}\text { NON-INTERACTIVE } \\
\text { Single Voice }\end{array}$} \\
\hline $\begin{array}{l}\text { DIALOGIC } \\
\text { Many Ideas }\end{array}$ & $\begin{array}{l}\text { Dialogic interactive } \\
\text { Many voices and many ideas }\end{array}$ & $\begin{array}{l}\text { Dialogic non-interactive } \\
\text { Single voice but many ideas }\end{array}$ \\
$\begin{array}{l}\text { AUTHORITATIVE } \\
\text { Single Idea }\end{array}$ & $\begin{array}{l}\text { Authoritative interactive } \\
\text { Many voices but single idea }\end{array}$ & $\begin{array}{l}\text { Authoritative non-interactive } \\
\text { Single voice and single idea }\end{array}$ \\
\hline
\end{tabular}

Scott and Ametller (2007) have emphasized that for effective science teaching to occur, it must involve both dialogic and authoritative dimensions. For example, if discussions are started with dialogical approach and students are given the opportunity to work on different ideas, then at some points, discussions should be ended with authoritative approach. The closure phase can be very important (for example, while explaining the difference between students' daily knowledge and scientific knowledge). Effective teachers often review the opinions that emerge during the conversation or summarize the explanations developed towards the end of the discussion. The teacher's this revision and summarization of the scientific knowledge are made possible through the authoritative non-interactive approach.

The basic principle for effective inquiry in science teaching to occur is that it should include opportunities for researching ideas in the inquiry process, comparing alternative explanations, testing and evaluating ideas, and for the whole class and small group discourse promoting evidence-based reasoning. Interventions and exploratory discussions that support teachers and students to use the dialogically interactive communicative approach in an effective way have significant and positive effects on learning process and product and cognitive development of students (Mercer et al., 2004). 


\section{Purpose of the Study}

The purpose of the current study is to determine the communicative approaches used in science education. In this regard, responses to the following questions will be sought:

1. What are the communicative approaches used by the pre-service teachers before and after the implementation of the training program?

2. What is the communicative approach often preferred by the pre-service teachers in their classes and the reasons for using this communicative approach before and after the implementation of the training program?

\section{Significance of the Study}

The research-inquiry process is considered not only as "exploration and experimentation" but also as a process of generating "explanation and argument". Research-inquiry based learning is a student-centered learning in which students feel the desire to explore everything in their surroundings, build strong arguments by making evidencebased explanations about the natural and physical world around them, and grow up as individuals who are excited and knowledgeable about science, in short, it is an approach through which students construct the knowledge in their minds like a scientist by experiencing-doing-thinking. Teachers encourage their students to take part in dialogues in which they can express their ideas comfortably, support their ideas with a variety of evidence, and develop counter arguments to refute their friends' claims. In written or oral discussions involving counter arguments, teachers take on the role of guidance during discussions generated and directed by students on the basis of reliable data and evidence (Ministry of National Education, 2013).

One of the key principles of the inquiry-based science education is the requirement that the inquiry process should include opportunities for the examination of questions and opinions as well as opportunities to enable students to make reasoning on the basis of evidence and opinions. Therefore, teaching and learning science captures the teacher's directing the discourse promoting inquiry and students' participating in conversations promoting their learning (Hackling, Smith and Murcia, 2010). However, the research has revealed that though the curriculums are built on these principals of inquiry, in practice authoritative discourses have been used more than necessary and inquiries have been prevented through the teacher directions (Lehesvuori, Ratinen, Kulhomaki, Lappi and Viiri, 2011; Ryder and Leach, 2006). The reason for this is explained by Pimentel and McNeill (2013) in their study investigating science classes as follows: though teachers believe that the classroom discussions they manage are not ideal, they go on demonstrating authoritative attitudes. That is, though teachers know that they should not use authoritative approaches, they frequently make use of them in their classes. According to Mercer, Dawes and Staarman (2009), the reason for the frequent use of authoritative approaches is their relative easiness of implementation compared to dialogic approaches.

Teachers need to use dialogic approaches to encourage students to be involved in dialogues in which they can express their ideas comfortably, support their ideas with a variety of evidence, and develop counter arguments to refute their friends' claims. However, although there is a limited amount of research in our country about the discourses used by science teachers in science teaching (Akış, 2012; Kanadlı and Sağlam, 2012), there are a lot of international studies focusing on the discourses used by teachers to teach the subjects in science curriculums in their classes (Mortimer and Scott, 2003; Lehesvuori, Viiri and Puttonen, 2010; Monilari, Mameli and Grisci, 2012; Pimentel and McNeil, 2013; Löfgren, Schoultz, Hultman and Björklund, 2013; Lehesvuori, Viiri and Puttonen, 2011). Moreover, when the domestic literature is reviewed, it is seen that while there is some research pointing to the need of using dialogic approaches in argumentation works by teachers (Demirbağ, 2017) and to teach the nature of science to students (Kaya et al., 2016), there is no study aiming to introduce dialogic instruction and communicative approach to pre-service teachers and investigating how they use them in their classes. In this connection, only one study was encountered looking at the effectiveness of a professional development program designed to improve science teachers' classroom discourse (Kanadlı and Sağlam, 2016). In this context, the preservice teachers were informed about the concepts of dialogic instruction and communicative approach and a 7week training program was developed and applied to raise their awareness of dialogic teaching and communicative approach. The use of dialogic approaches, a group of communicative approaches, by science teachers in science classes within the context of the current study is believed to yield valuable insights into how they can be used in inquiry-based science teaching, in teaching the nature of science to students, in argumentation applications and in STEM (Ortman, 2015) applications. 


\section{Method}

\section{Research Model}

The current study was conducted within the context of a doctoral dissertation aiming to support the professional development of senior pre-service classroom teachers. The purpose of the current study presented here is to determine the communicative approaches used by two pre-service teachers in science teaching. To this end, the discourse analysis method was used to determine the communicative approaches used in the class. For the discourse analysis, the lessons of the pre-service teachers selected from the participating group were used as sample cases.

\section{Study Group}

The current study was conducted on two volunteer senior students having taken the course of "Practicum Teaching" in the spring term of 2012-2013 academic year in the Department of Science Teaching at the Elementary Education Program of the Education Faculty of Pamukkale University. The pre-service teachers had never encountered the concept of communicative approach before the study. Though many pre-service teachers participated in the study on a volunteer basis, only one male and one female pre-service teacher thoroughly completed the training; thus, only their data were used in the analyses. Pseudo-names were given to these two participants and these names will be used hereafter. The sampling process in discourse analysis is different from the sampling process in other research techniques because discourse analysis is concerned with the language used in a text or a discourse whereas other research methods are concerned with people. In other words, it is not the people who use the language, but the language itself is the focus of discourse analysis. In this sense, there is no sampling directed to people in discourse analysis. This makes it possible to conduct discourse studies with smaller samples. Actually, a larger sample makes it difficult to analytically manage the study; in addition, does not make important contributions to the research findings (Elliot, 1996; cited in Baş and Akturan, 2008).

\section{Data Collection Process}

At the beginning of the study, one lesson of each pre-service teacher was video-recorded to determine the communicative approaches they used in their lessons. During the video-recording, the pre-service teachers did not know the reason why their lessons were video-recorded. They were video-recorded by their peers. Then, in order the raise the pre-service teachers' awareness of dialogic instruction and communicative approach, a seven-week training program was developed and applied. The pre-service teachers were subjected to this training two hours a week. The general objective of this training was to maintain the existence and application of communicative approach (e.g. theoretical explanations, samples and applied activities). Training was given as follows through the seven-week period:

As majority of the pre-service teachers stated that they did not know much about the renewed 2013 science curriculum, it was decided to inform them about this renewed program in the first week of the training and to talk about teacher and student roles. In the second week, a presentation was prepared and made to the students about what science teaching and science learning is and how dialogic instruction should be according to Vygotsyk's viewpoint. In the third week, the pre-service teachers were informed about the theoretical framework of communicative approach developed by Mortimer and Scott (2003). In the fourth week, sample science lesson plans (about the subject of corrosion) prepared by Mortimer and Scott (2003) were shown to students to illustrate how each communicative approach can be used in the class. In these sample lesson plans, it is possible to see how each communicative approach is used through a series of lessons by the teacher and how students' daily language is translated into scientific language. In the fifth week, the teacher translated the episodes given in the article "An Investigation of Dialogic Teaching in Science Classrooms" (Scott, Ametler, Staarman and Mercer, 2007) to clarify how different communicative approaches are used in the class, putting particular emphasis on the dialogicinteractive communicative approach and presented them to the pre-service teachers. In this article, concept cartoons are used to initiate the dialogic interaction. And in the lesson plans, it is stated that in the initiation and development of classroom discussions, argumentations, guess-observe-explain, concept cartoons etc. can be used and some sample applications were performed with the pre-service teachers. In the sixth week, the teacher again translated the article "The Tension Between Authoritative and Dialogic Discourse: A Fundamental Characteristic of Meaning Making Interactions in High School Science Lessons (Scott, Mortimer and Aguiar, 2006)" and its episodes were presented to the pre-service teachers to make them better understand how different communicative 
approaches are used in the class and the tension between all the communicative approaches. In the seventh week, in order to illustrate how productive classroom communications should be, a presentation was prepared and shared with the pre-service teachers (Uçak, 2014).

At the end of the training, the pre-service teachers were asked to prepare lesson plans in line with the objectives of the subject to be studied in the class by the science teacher in the given week. The participating pre-service teachers planned their lessons to last 40 minutes and delivered them in the application school. After the training, the lessons delivered by the pre-service teachers were also video-recorded by their peers. Following the completion of the video-recordings, the pre-service teachers watched their pre-training and post-training lesson recordings and they were asked to write about the communicative approaches they think they frequently used in their lessons and the rationales for their selection of these communicative approaches. Thus, the communicative approaches frequently used by these two pre-service teachers in their lessons and the rationales behind their preference for these approaches were determined.

\section{Data Analysis}

The basic data source of the study is the video-recordings of the pre-service teachers. These video-recordings were subjected to discourse analysis by using the MAXQDA 11 program package. By calculating how long which communicative approach was used in the dialogues having occurred in the lessons of each teacher, the general tendency of the pre-service teachers was attempted to be elicited. After the transcription of the video-recordings, the dialogues re-read in company with the video images and codes were produced.

Discourse analysis is a type of qualitative analysis in which written texts are subjected to a detailed linguistic analysis (Özdemir, 2010). Discourse analysis is based on the discourse and built on the analysis of daily sentences or texts within the context of the discourse. Different from the content analysis, discourse analysis attempts to find the real meanings of words, sentences and expressions (Baş and Akturan, 2008).

The codes of the data analysis concerning the video-recordings were derived from the communicative approach defined by Mortimer and Scott (2003) and are as follows:

- Authoritative interactive: There are question-answer routines, very little time is allocated to alternative and different opinions and student answers are frequently subjected to evaluation.

- Dialogic interactive: Students' opinions (e.g. daily knowledge) are explored without being judged and they are capitalized on. The teacher does not seek for a specific point of view; rather, tries to elicit students' viewpoints in a purposeful manner and works on conflicting opinions.

- Authoritative non-interactive: The teacher clearly presents the scientific knowledge mostly by means of lecturing.

- Dialogic non-interactive: From the students' conflicting opinions having been previously stated, the teacher proceeds towards scientific opinions. Meanwhile, he/she does not interact with students.

By watching the video-recordings of each pre-service teacher, they were analyzed on the basis of the codes defined above through discourse analysis. In light of these codings, it became possible to see the communicative approaches used by the pre-service teachers throughout the lesson. With the transcriptions of the video-recordings, the communicative approaches used by the pre-service teachers were exemplified.

While analyzing the data, a video-recording of a pre-service teacher randomly selected was coded by two researchers having qualitative research experience and having participated in communicative approach trainings and then inter-rater coefficient was calculated. Then, these two researchers came together to examine the consistency between their analyses and discussed differently addressed codes to reach an agreement. In the calculation of the consistency coefficient;

$\mathrm{P}=[\mathrm{Na} / \mathrm{Na}+\mathrm{Nd}] \times 100$ (Miles and Huberman, 1994: 69) formula was used. The inter-rater coefficient was calculated and is presented in Table 3. 
Table 3. Inter-rater Reliability

\begin{tabular}{cccc}
\hline Data Set & $\begin{array}{c}\text { Number of Agreement } \\
(\mathrm{Na})\end{array}$ & $\begin{array}{c}\text { Number of } \\
\text { Disagreement } \\
(\mathrm{Nd})\end{array}$ & Ratio of Agreement (P) \\
\hline $\begin{array}{l}\text { The Video-Recording } \\
\text { of the Pre-service } \\
\text { Teacher Aylin }\end{array}$ & 73 & 7 & 91.25 \\
\hline
\end{tabular}

At the same time, after the completion of training, the pre-service teachers were asked to watch their own video-recordings and to report the communicative approaches they had used through discourse analysis. Furthermore, an expert outside the current study was invited to watch the video-recording of a pre-service teacher randomly selected and to examine the discourse analysis report formed as a result of the linguistically-oriented reliability study and to give feedbacks. The codes of the data analysis related to the video-recordings were derived from the communicative approach defined by Mortimer and Scott (2003). The discourse analysis was conducted according to these codes. Agreement was reached on these codings and teacher-student and student-student dialogues could easily be gathered under these categories. Thus, the research findings can be tested in similar environments. In this regard, by giving detailed information about all the stages of the study, the validity of the study was established.

\section{Findings}

The Communicative Approach Used by the Pre-service Teachers in their Lessons before and after the Training Program

The analysis of the lessons of the pre-service teachers before and after the training program revealed that both pre-service teachers used the similar communicative approaches before and after the training program. The preservice teacher Aylin's in-class applications before the training program are exemplified below.

\section{The pre-service teacher Aylin's in-class applications before the training program}

The pre-service teacher Aylin conducted her practicum teaching in the science classes of the sixth grade students. The pre-service teacher taught the subject "the structure of blood" in her lesson delivered before the training program. Below can be seen that graph (Graph 1) of the analysis of the pre-service teacher Aylin's lesson video in terms of the communicative approach.

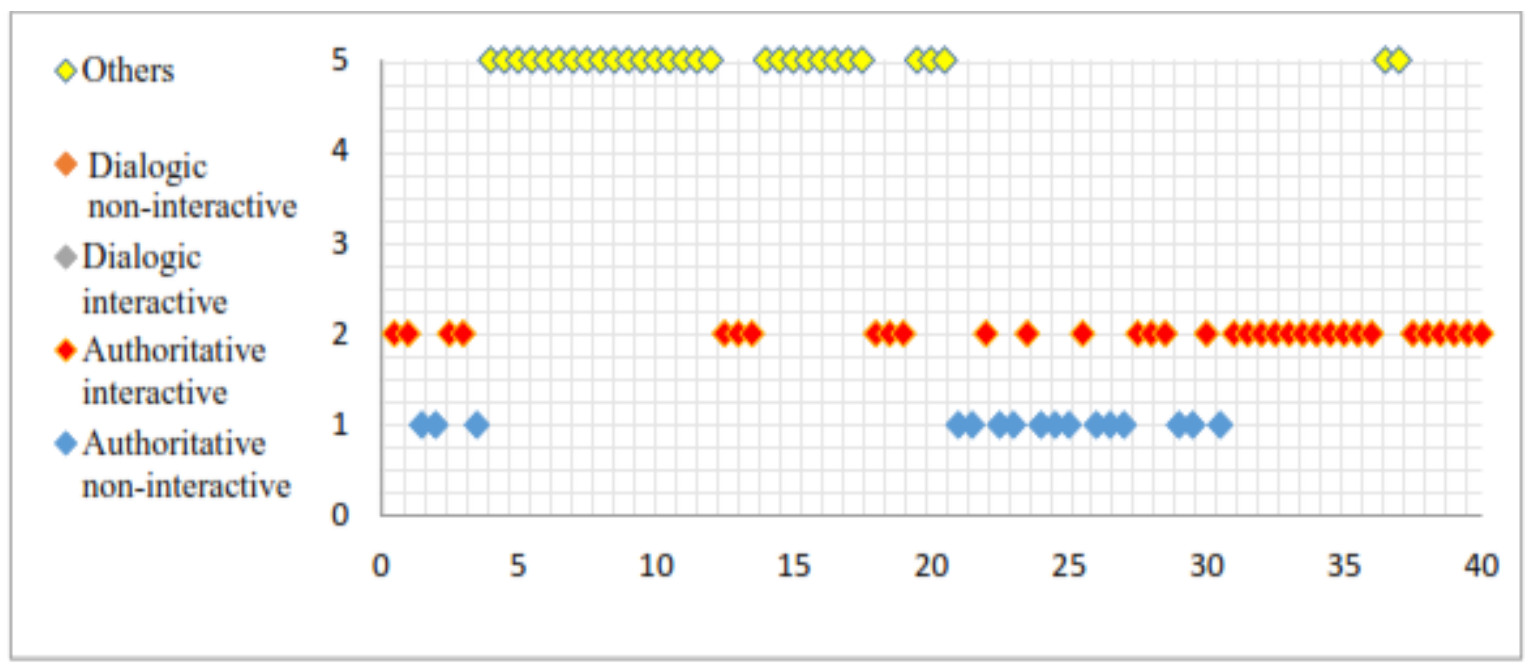

Graph 1. The Graph of the analysis of the pre-service teacher Aylin's lesson video before the training program in terms of the communicative approach 
* In the graph, the horizontal axis refers to the time in minutes and the vertical axis refers to the communicative approach. What is meant with others is the cases in which there is no communication such as the teacher's announcements, switching on and off the video, students' watching images in the microscope or watching videos or out-of-class discourse.

As can be seen in Graph 1, the pre-service teacher Aylin preferred the authoritative interactive and authoritative non-interactive communicative approaches in her lesson. The pre-service teacher Aylin started her lesson with the authoritative interactive approach and a part of the discourse she used in her lesson is given below:

1. Aylin T: Now let's remember what are our microcurcilation and macrocurcilation organs; can you tell me? Which organs are they, yes?

2. S.12: Heart.

3. Aylin T: Yes, heart, what else.

4. S.22: Blood vessels.

5. Aylin T: Yes, there are blood vessels, yes, you?

6. S.17: Blood.

7. Aylin T: There is blood.

8. S.23: Kidney.

9. Aylin T: Yes, there is the kidney, it flows through the kidney.

10.S.12: Lung.

11. Aylin T: Yes, there is the lung.

12.S.22: Artery.

13. Aylin T: Yes, we have the artery.

14.S.23: Vein.

15. Aylin T: We have the vein.

16.S.12: Capillary vessel.

17. Aylin T: Yes, we have capillary vessels.

18.S.17: Capillary vessel.

19. Aylin T: We have already said, yes we have capillary vessels.

20.S. 27: Teacher!

21. Aylin T: Yes, Mehmet.

22.S. 27: There is the aorta.

23. Aylin T: Yes, there is the aorta.

24. S. 27: There is the lung artery.

25. Aylin T: Yes, there is the lung artery.

26. Aylin T: Yes, in our lesson last week we learned the duties of our blood vessels, how they carry the blood, how it is cleaned in our lungs and then how it circulates our body and gets dirty. In our lesson today, I think you remember in our first lesson we likened our body to a city center and the blood vessels to the roads in this city center. Now we have remembered our blood vessels. Now, what is the structure that orders the concerned organ to clean the dirty blood? That is, what is there in our blood, that is cleaned and polluted, carries oxygen and nutrients? Blood, isn't it, children?

In this part of the discourse, the pre-service teacher Aylin receives answers to an closed-ended question she has asked to students until the $26^{\text {th }}$ dialogue. The pre-service teacher Aylin only confirms the students' answers in 388 
$3^{\text {rd }}, 5^{\text {th }}, 7^{\text {th }}, 11^{\text {th }}, 13^{\text {th }}, 15^{\text {th }}, 17^{\text {th }}, 19^{\text {th }}, 23^{\text {rd }}$ and $25^{\text {th }}$ dialogues. In the $26^{\text {th }}$ dialogue, she continues her lesson by using the authoritative non-interactive communicative approach.

The pre-service teacher adjusted the two microscopes she brought to the class. Then, she invited each student to the table to look at the image seen in the microscope and then asked them to draw it in their notebooks. As the classroom was crowded and as there were only two microscopes, this activity took a long time. Meanwhile, as there was no communication occurring between the teacher and the students apart from the instructions, these parts (time between the $5^{\text {th }}$ and $13^{\text {th }}$ minutes) were analyzed under the group of others.

In the following sections of the class, the pre-service teacher continues her lesson by asking closed ended questions about red blood cells, white blood cells and blood-platelets up to the end of it by using the authoritative interactive communicative approach. The communicative approach used by the pre-service teacher Aylin is shown by percentages on the following pie chart (Graph 2).

\section{The communicative approaches used by the pre-service teacher Aylin in her lesson before the training program}

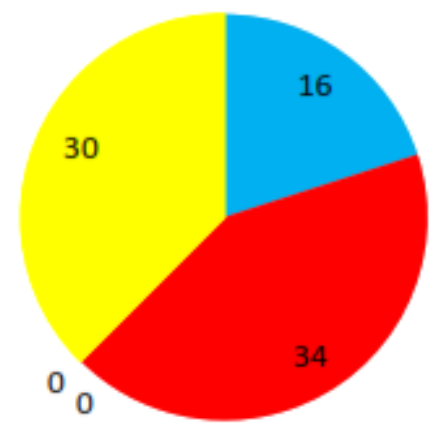

Authoritative non-interactive

- Authoritative interactive

- Dialogic interactive

Dialogic non-interactive

Others

Graph 2. \% graph of the pre-service teacher Aylin's lesson video before the training program in terms of the communicative approach

As can be seen in Graph 2, the pre-service teacher used the authoritative interactive approach (34\%) and authoritative non-interactive approach $(16 \%)$ in her lesson before the training program. When the pre-service teacher Aylin's lesson is examined in terms of the communicative approach before the training program, it is seen that in much of the lesson she used the authoritative interactive communicative approach. That is, in much of the lesson, the teacher's discourse is comprised of the cycle of initiation-response-evaluation and most of it is made up of the questions asked to receive the answers clear in the teacher's mind and evaluation of them.

The pre-service teacher Aylin's opinions about the communicative approach she used in her lesson before the training program

The pre-service teacher Aylin was asked to write her opinions about the communicative approach she frequently used in her lesson after watching the video and the reasons for her using this communicative approach. The pre-service teacher expressed her opinions in this regard as follows:

"In general I used the authoritative interactive communicative approach in my lesson because I directed the lesson according the questions I asked and the responses students gave to these questions. These questions were closed ended knowledge-based questions. They did not require any inquiry. I used the authoritative interactive communicative approach in order to maintain the control in the class. When I watched the video, I realized that when I showed them an image in the microscope and then tried to elicit their guesses about the image and made them draw what they had seen, it was not very effective. That is, I asked them to look at the image and draw it; yet, as the students did not have any information about the subject, they did not draw the image. Even a few students said "How I can draw the thing I do not know?" because I only adhered to the plan I had prepared and the questions to be asked in line with this plan. My objective was to remain adhered to the plan. I did not focus on whether the students learned the subject 
within the context of this plan. I continuously allowed the students raising their hands to answer throughout the lesson. In fact, I would have let other students talk so that I could have started a discussion. However, as I have already said, my sole aim was to implement my lesson plan and make students find the correct answer. As such, I mostly used the authoritative interactive communicative approach.

When the pre-service teacher Aylin's evaluations of her lesson are examined, it is seen that she is of the opinion that her lesson was mostly conducted in line with the authoritative interactive communicative approach. The findings of the analysis of the video recording of her lesson (Graph 2) also revealed that the pre-service teacher Aylin utilized the authoritative interactive communicative approach in her lesson.

\section{The pre-service teacher Aylin's classroom applications after the training program}

The lesson delivered by the pre-service teacher Aylin after the training program was conducted with the same group of students as the one before the training program. After the training program, the pre-service teacher taught the subject "sound insulation". Below is seen the analysis graph (Graph 3) of the pre-service teacher Aylin's lesson video recorded after the training program in terms of the communicative approach.

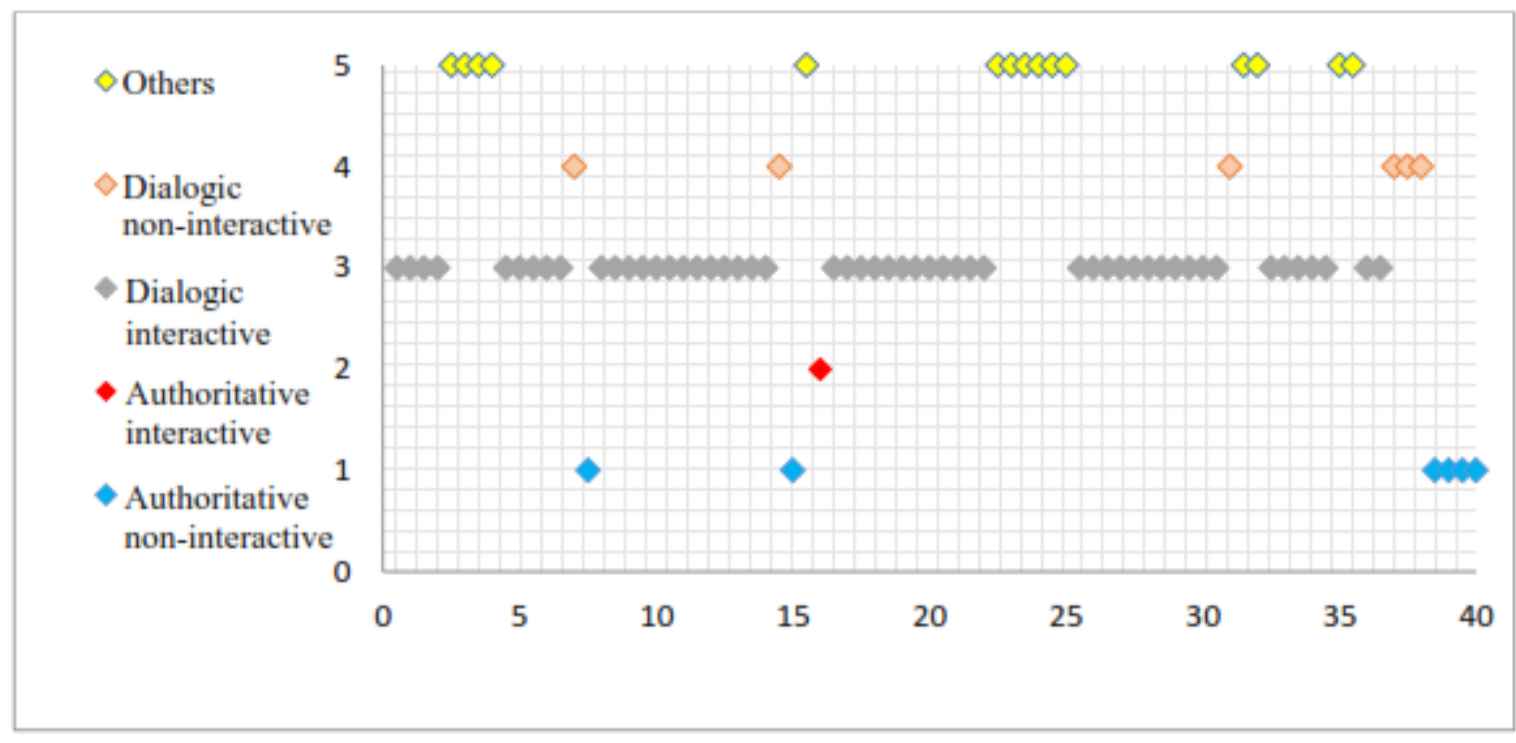

Graph 3. Analysis graph of the pre-service teacher Aylin's lesson video recorded after the training program in terms of the communicative approach

The pre-service teacher Aylin starts her lesson with questions to elicit what the students know about the sound and uses the dialogic interactive communicative approach. In the $3^{\text {rd }}-4^{\text {th }}$ minutes of the lesson considered within the others group, the pre-service teacher finds concept cartoons in the computer and asks each student to silently read the concept cartoons. Then, she starts to question the students to find out which of the characters depicted in these cartoons they agree with. During this questioning stage, she uses the dialogic interactive communicative approach. During the flow of the lesson, she sometimes summarizes the dialogues; thus, making use of the dialogic non-interactive communicative approach. The $15^{\text {th }}$ minute seen in Graph 3, evaluated within the others category, she divides the students into groups and continues the lesson by using the authoritative interactive communicative approach.

Before coming to the class, the pre-service teacher Aylin had put different items into boxes. After handing out the boxes to the groups, she asked the students to guess which items are inside the boxes. Below is given the dialogic interactive communicative approach section of the lesson:

1. Aylin T: Now, why do you think we are conducting the experiment?

2. S.16: To find out which insulates better, teacher.

3. Aylin T: Yes, we are doing to find out which one is insulating better. Then, let's guess it 
4. S.16: The best one is the egg cardboard box.

5. Aylin T: Which one do you think insulates better, yes what do you think?

6. S. 27: Egg cardboard box.

7. Aylin T: But, compared to which one, the egg cardboard box insulates better?

8. S.27: Better then the foam.

9. Aylin T: Your friend says that the egg cardboard box insulates better then the foam. Is there anyone agreeing with your friend?

10.S.1: I do.

11. Aylin T: Is there anyone who disagrees?

12.S.5: In my opinion, the cleaning cloth.

13. Aylin T: We are talking about the egg cardboard box and the foam now.

14.S.5: In my opinion, it is the egg cardboard box.

15. Aylin T: Is there anyone disagreeing and saying that "I am thinking different because ..."

16. S.38: My teacher, the foam insulates better because there is space in it.

17. S.20: But, there is space within the cardboard box.

18.S.38: Doesn't the foam insulate better?

19.S.20: There is space within the egg cardboard box.

20. Aylin T: Yes, but your friend says "there is space within the egg cardboard box". What do you want to tell about your friend's opinion? One of your friends says that there is space in the foam; therefore, it insulates better, another says that there is space within the egg cardboard box as well.

21. Aylin T: Yes, Aylin.

22. S.16: In my opinion, the egg cardboard box insulates better because we have seen it an experiment.

23. Aylin T: What kind of experiment was it Aylin, can you explain it a bit?

24. S.16: They put a clock inside a box and one inside the egg cardboard box and then the teacher closed the box, and the sound of the clock was not heard outside.

25. Aylin T: So, why did you select the egg cardboard box? Why the egg cardboard box?

26. S.5: Teacher, in my opinion, the egg cardboard box is thinner.

27. Aylin T: So, you mean thinness is effective. Then, why the egg cardboard box?

28.S.5: I do not know.

29. Aylin T: Why the egg cardboard box? Yes, Mehmet, what do you think?

30. Ö.28: The egg cardboard box have inner parts and dented parts. These parts make up a design that can provide sound insulation and they can be used inside buildings and on their roofs.

31. Aylin T: Then, what is the use of the vertical and dented parts in sound and heat insulation?

32. Ö.28: While the vertical parts reduce the sound, the dented parts prevent the sound from reaching the other side. In this way, both the exit and the entry of the sound is prevented.

33. Aylin T: Is there anyone agreeing with Mehmet?

34. Ö.16: In my opinion, Mehmet is right, yes because of its design.

The pre-service teacher Aylin, by using the materials found in the boxes, elicited the students' guesses about why they were doing the experiment. She asked for the students' alternative opinions and questioned whether the 
students agreed with their friends without subjecting them to any evaluation. The pre-service teacher Aylin gave impartial feedbacks in response to students' answers. Moreover, she wanted them to explain and justify their opinions. She continued her lesson by using the dialogic interactive communicative approach for the other materials inside the boxes.

The pre-service teacher Aylin elicited the students' opinions and listed them on the board. He tried to convert the students' daily knowledge into scientific knowledge step by step. At the end of the lesson, by conducting the experiment, compared the guesses with the findings.

Aylin T: You produced some guesses, now let's check whether your guesses are correct or false. During the experiment, you can take notes to make a comparison.

The pre-service teacher Aylin handed out the experiment materials to the students and wanted them to focus on the sound of the clock inside the boxes and asked them to determine which material insulates the sound better. Though there was a group putting the materials into the correct order in terms of their sound insulation performance, she replicated the experiment for all the groups to reach the correct order. She asked them to listen carefully to the sound coming from the boxes placed on the student desk in the front. A part of the related discourse is given below:

35. Aylin T: First we listen when the box is empty, everybody, listen. Now first I will put a cleaning cloth in the box. Now listen. Does everybody hear? Now we will try the cotton. First I tried the cleaning cloth and now I am trying the cotton.

36. Students: The cotton.

37. Aylin T: What did we say finally?

38. Students: The cotton.

39. Aylin T: Now, is there anyone changing his/her guess?

40. Group 1: We are.

41. Group 3: We are.

42. Aylin T: I am eliminating these (some in the list on the board are deleted.)

43. Aylin T: We reduced them to two options, didn't we? Now the cotton is better than the cleaning cloth, what was the cleaning cloth better than, according to you?

44. Ö.9: The cotton.

45. Ö.5: Teacher!

46. Ö.38: The egg cardboard box.

47. Aylin T: The egg cardboard box, now shall we try the cleaning cloth and the egg cardboard box?

48. Students: Yes.

49. Aylin T: Let's try the egg cardboard box and the foam. Now the foam.

50. Ö.5: Teacher! I think the egg cardboard box insulates less than the foam .

51. Aylin T: Ok, now let's try, Zülal has another idea. She says that the foam is better than the egg cardboard box, we can try this. The egg cardboard box and the foam. First I am putting the foam. I have put it and closed the box. I have put the foam. You are listening, aren't you?

\section{Students: Yes.}

The pre-service teacher Aylin realized that the students ran into a contradiction and at that point, instead of directly telling the correct answer, she preferred to reiterate the experiment for the students to continue questioning. Without making any evaluation, the pre-service teacher attempted to 
understand her students' opinions and to encourage those who had different opinions to express their thoughts.

53. Aylin T: We are first trying the foam. Listen to me for a second. Now, I am trying the egg cardboard box. I think it is the egg cardboard box.

54. Aylin T: As far as I understand Zülal has changed her opinion, what are you thinking Zülal?

55. Ö.5: At first, the sound was weaker than it is now.

56. Aylin T: Just for a second listen to Zülal. She is saying something. What was the previous guess of Zülal? Zülal?

57. Ö.5: The foam?

58. Aylin T: She said that the foam insulates better, what about now ...

59. Ö.5: The egg cardboard box.

60. Aylin T: What about you? Do you agree with her?

61. Students: Yes teacher, we do.

62. Aylin T: Do we need to repeat it?

63. Students: No, teacher.

The pre-service teacher elicited the contradictions of the students and helped them to get rid of their contradictions on their own through dialogues. While doing this, she used the dialogic interactive communicative approach. Then the pre-service teacher continued her lesson by using the dialogic non-interactive communicative approach summarizing the students' dialogues.

Aylin T: Ok, Zülal has changed her opinion. As a result of the experiment we conducted, she changed her opinion. Finally we can summarize what you have said. What are the findings we agreed on on the basis of your opinions on the board? You came up with the order of materials ranging from the most insulating to the least insulating: Cotton, cleaning cloth, the egg cardboard box, foam, bottle. At first, you couldn't decide which one is better, the foam or the egg cardboard box, then we reiterated the experiment after that you were able to decide which one is better and you decided on your order of the materials.

The pre-service teacher, at the end of her lesson, finished the lesson by presenting the scientific viewpoint in an authoritative non-interactive manner. The communicative approach used by the pre-service teacher Aylin is shown by percentages on the following pie chart (Graph 4).

\section{The communicative approaches used by the pre-service teacher Aylin in her lesson after the training program}

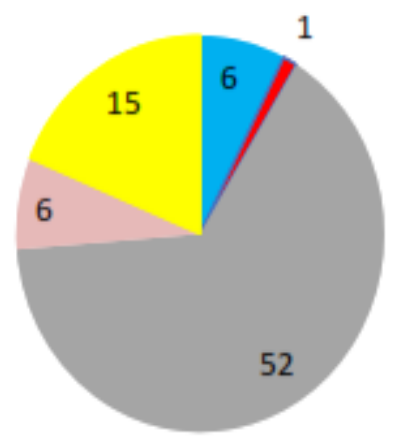

Authoritative non-interactive

Authoritative interactive

Dialogic interactive

Dialogic non-interactive

Others

Graph 4. \% graph of the pre-service teacher Aylin's lesson video recorded after the training program in terms of the communicative approach 
As can be seen in Graph 4, the pre-service teacher used the authoritative interactive (1\%), the authoritative non-interactive $(6 \%)$, the dialogic interactive $(52 \%)$ and the dialogic non-interactive $(\% 6)$ approaches. It is seen that after the training program, the pre-service teacher spent much of her lesson using the dialogic interactive approach. After the training program, the pre-service teacher Aylin adopted the role of a teacher taking care of her students' opinions, asking students to verify their explanations, encouraging students to discuss different opinions. The pre-service teacher started to give chance to express their views and comment on the subjects and opinions emerging during the lesson. Moreover, without judging the students' opinions, she paid attention to all of them and allowed dialogues to continue.

The pre-service teacher Aylin's opinions about the communicative approach she used in her lesson after the training program

The pre-service teacher Aylin expressed her opinions about her lesson after the training program as follows:

"In fact what is important is the effective and meaningful use of the selected communicative approach in such a way as to elicit students' opinions. Selection of the communicative approach that will arouse excitement and curiosity in students in line with the subject to be addressed and the objectives to be achieved is of great importance. Yet, to do so is not possible through authoritative approaches. Therefore, we need to use dialogic approaches. Thus, I think I made use of dialogic approaches in my last lesson. Moreover, in order to be able to determine the direction of the lesson on the basis of students' opinions, you cannot adhere to your lesson plan. In addition, while I was planning my last lesson plan, I spent a large amount of time, I did more research and I thought more. I pondered about the questions to be posed by students. I did the preparation in this way. I may have tried to direct them with my questions. Moreover, the feedback I receive from my students is very important for me. If my student come to realizations such as" hulm I have understood it now" or "that is the reason for this", then I consider myself successful. In my last lesson, as I had already started in this way, I think I made much use of the dialogic interactive communicative approach".

In her evaluation of her own lesson, the pre-service teacher Aylin pointed out that she had made much use of the dialogic interactive communicative approach. As a result of the analysis of her lesson video (Graph 4), it was also revealed that the pre-service teacher used mostly the dialogic interactive communicative approach as she said.

\section{The pre-service teacher Yasin's in-class applications before the training program}

The pre-service teacher Yasin conducted his practicum teaching in the science lessons of the seventh graders. In the lesson he conducted before the training program, the pre-service teacher taught the subject "concentrated and diluted solutions". Below can be seen that graph (Graph 1) of the analysis of the pre-service teacher Yasin's lesson video before the training program in terms of the communicative approach (Graph 5). 


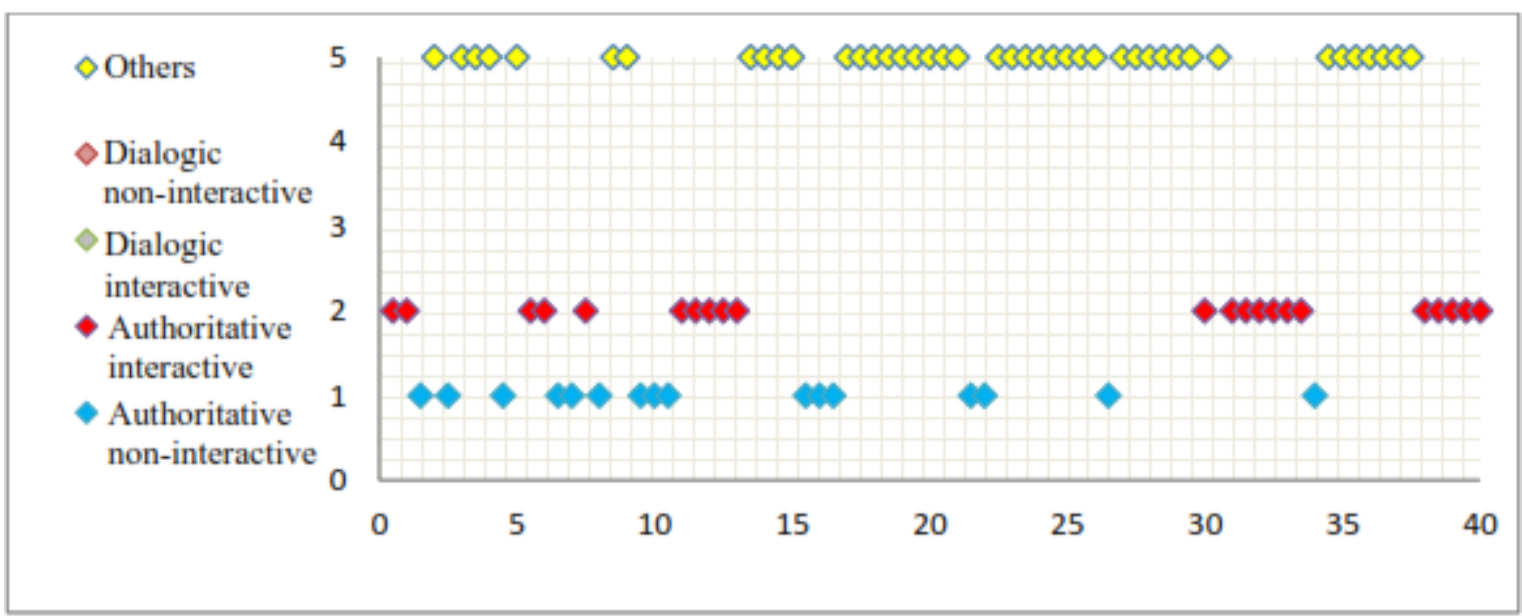

Graph 5. The graph of the analysis of the pre-service teacher Yasin's lesson video before the training program in terms of the communicative approach

As can be seen in Graph 5, the pre-service teacher mostly used the authoritative interactive and authoritative non-interactive communicative approaches in his lesson. The pre-service teacher Yasin started his lesson by using the authoritative interactive communicative approach and one section of his lesson dominated by this approach is given below:

1. Yasin T: What is the solvent in salty water?

2. S.10: The solvent is salt.

3. S.7: The solvent is water.

4. S.8: The solvent is water.

5. S.10: Water, water.

6. S.8: Salt is the solute.

7. Yasin T: Yes, friends, salt is the solute.

8. Yasin T: Do you remember how much salt can water dissolve in solutions? Or if we go on adding water, can it dissolve all the salt?

9. S.3: No.

10. S.15: No, it cannot.

11. Yasin T: Some of it is left, sometimes, isn't it?

12. S.3: Yes.

13. Yasin T: Let me ask you a question. If we add some salt into water or we put something different like a sugar cube or several sugar cubes, does it solve both of them?

14. S.7: Yes.

15. S.8: It does.

16. Yasin T: It solves both of them, doesn't it?

17. Yasin T: But, are both of the solutions same?

18. Students: No.

19. S.7: One dissolves faster and the other slower.

20. Yasin T: Let me correct it; one dissolves more and the other less.

21. S.7: Yes.

In the first dialogue the pre-service teacher asks what is the solvent in salty water and in $2^{\text {nd }}, 3^{\text {rd }}, 4^{\text {th }}, 5^{\text {th }}$ and $6^{\text {th }}$ dialogues; though he receives alternative answers from students, he verifies the correct answer in the $7^{\text {th }}$ dialogue. In the following dialogues, he asks closed ended questions $\left(8^{\text {th }}, 13^{\text {th }}\right.$ and $\left.17^{\text {th }}\right)$, he verifies the correct answers.

In the following sections of the lesson, the pre-service teacher hands out the experiment materials to the students sitting as a group in their desks combined and explains what they need to do by using the authoritative non-interactive communicative approach. Each group is given three beakers and asks them to put a sugar cube in the first beaker, two sugar cubes in the second beaker and three sugar cubes in the third beaker. Then the students mix the sugar cubes in the beakers within the time period named as others in the graph. Meanwhile there is no 
teacher-student and student-student interaction. Only one or few of the groups mix the sugar cubes in the beakers. The other students chat with each other. Only interaction of the pre-service teacher with the students during this period involves warning reminding the students to be quit and focus on the experiment.

In the time period ranging from the $5^{\text {th }}$ minute and $10^{\text {th }}$ minute in Graph 5, the pre-service teacher frequently uses the authoritative non-interactive communicative approach. He writes what concentrated and diluted solutions are on the board and asks students to write down what is written on the board on their notebooks. The pre-service teacher Yasin distributes worksheets to the students towards the end of the lesson for evaluative purpose and asks the students to complete the worksheets individually. Between the $37^{\text {th }}$ and $40^{\text {th }}$ minutes he uses the authoritative interactive communicative approach and gives feedbacks for students' answers. Below is given the authoritative interactive dialogues occurring in this time period:

22. Yasin T: Yes, friends what did you say for the first question?

23. Ö.19: Solution.

24. Yasin T: Correct answer, the second question.

25. S.15: Solute.

26. Yasin T: Adem?

27. S.15: Solute, teacher.

28. S.8: Solvent.

29. S.19: Solvent.

30. S.11: Solution, teacher.

31. S.8: Solute.

32. S.6: What solute?

33. Yasin T: The second question solute. The third question?

34. S.8: Solvent.

35. Yasin T: Solvent. The fourth question.

36. Ö.8: Concentrated.

37. Ö.18: Concentrated.

38. Yasin T: Concentrated. The fifth question.

39. Students: Diluted.

40. Yasin T: What?

41. Students: Diluted.

42. Yasin T: Ok, friends, the lesson is over.

The pre-service teacher Yasin asks the students to answer the questions in the worksheet. While evaluating the answers given by the students, though he receives different answers to the second question $\left(25^{\text {th }}, 27^{\text {th }}, 28^{\text {th }}, 29^{\text {th }}\right.$, $30^{\text {th }}$ and $31^{\text {st }}$ dialogues), he does not inquiry for the alternative answers and in the $35^{\text {th }}$ dialogue, he gives the correct answer and that is all. In the fifth question, students have given their answers (in $39^{\text {th }}$ and $41^{\text {st }}$ dialogues) but the pre-service teacher does not give any feedback to the students' answers and finishes the lesson. 


\section{The communicative approaches used by the pre-service teacher Yasin in the lesson before the training program}

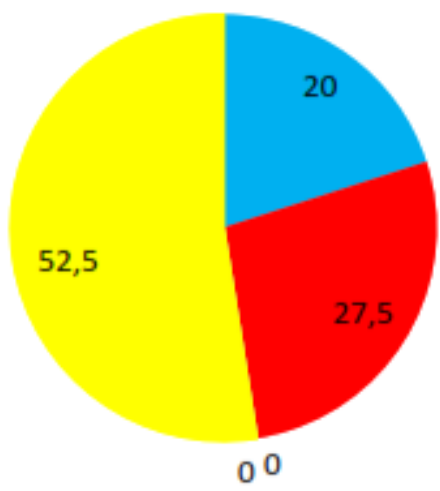

Authoritative non-interactive

Authoritative interactive

Dialogic interactive

Dialogic non-interactive

Others

gram in terms of the communicative approach

As can be seen in Graph 6, the pre-service teacher used the authoritative interactive (27.5\%) and authoritative non-interactive $(20 \%)$ communicative approaches in his lesson before the training program. Much of the lesson is spent within the structure called others. This section refers to time period in which the pre-service teacher is mostly quiet, announcements or warnings are made to students, students complete worksheets and there is no interaction between the teacher and students. In much of the lesson, the pre-service teachers warns the students to be quiet. In the sections defined as dominated by the authoritative non-interactive communicative approach, the pre-service teacher pointed to the scientific view and explained the subject himself. In the authoritative interactive sections, the pre-service teacher's discourse is mostly made up of the cycle of initiation-response-feedback and they are mostly in traditional nature in that the pre-service teacher directs closed ended questions to the students and evaluates the short answers given by the students. In some sections of the lesson, though some different answers are given by the students, the teacher ignores the false answer and verifies the correct one and proceeds through the next question.

The pre-service teacher Yasin's opinions about the communicative approach he used in his lesson before the training program

The pre-service teacher's opinions about his lesson are as follows:

"In the first lesson I taught I generally used the authoritative-interactive communicative approach. As the pattern of interaction, I used the question-answer-evaluate pattern. As we had not known the communicative approach before; I think, I unwittingly used the authoritative-interactive communicative approach because what is expected of us as teachers is to get students to participate in the lesson. Thus, we are continuously using question-answer-evaluate to get students to participate in the lesson. For instance, in my lesson when one of the students gave an answer, I immediately verified it if it was correct and if it was false, I directly provided the correct answer. I did not elicit the opinions of different students. I always interacted with the same students or I did not ask students to explain their thoughts or justify them. I did not ask almost any open ended questions. Moreover, I think, from time to time I used the authoritative non-interactive communicative approach as well. In my opinion, the reason for my using the authoritative non-interactive communicative approach was my concern about classroom management and fear of not being able to teach the scientific knowledge."

When the pre-service teacher Yasin's evaluation of his own lesson is examined, it is seen that he pointed out that he used the authoritative interactive communicative approach in much of the lesson. He also stated that from time to time, he used the authoritative non-interactive communicative approach as well. As a result of the video analysis (Graph 6), it was also found that the pre-service teacher mostly used the authoritative interactive and noninteractive communicative approaches in his lesson. 


\section{The pre-service teacher Yasin's classroom applications after the training program}

The lesson delivered by the pre-service teacher Yasin after the training program was conducted with the same group of students as the one before the training program. The pre-service teacher taught the subject "characteristics of stars and planets" in his lesson after the training program. Below is given the graph (Graph 7) of the analysis of the pre-service teacher Yasin's lesson video after the training program.

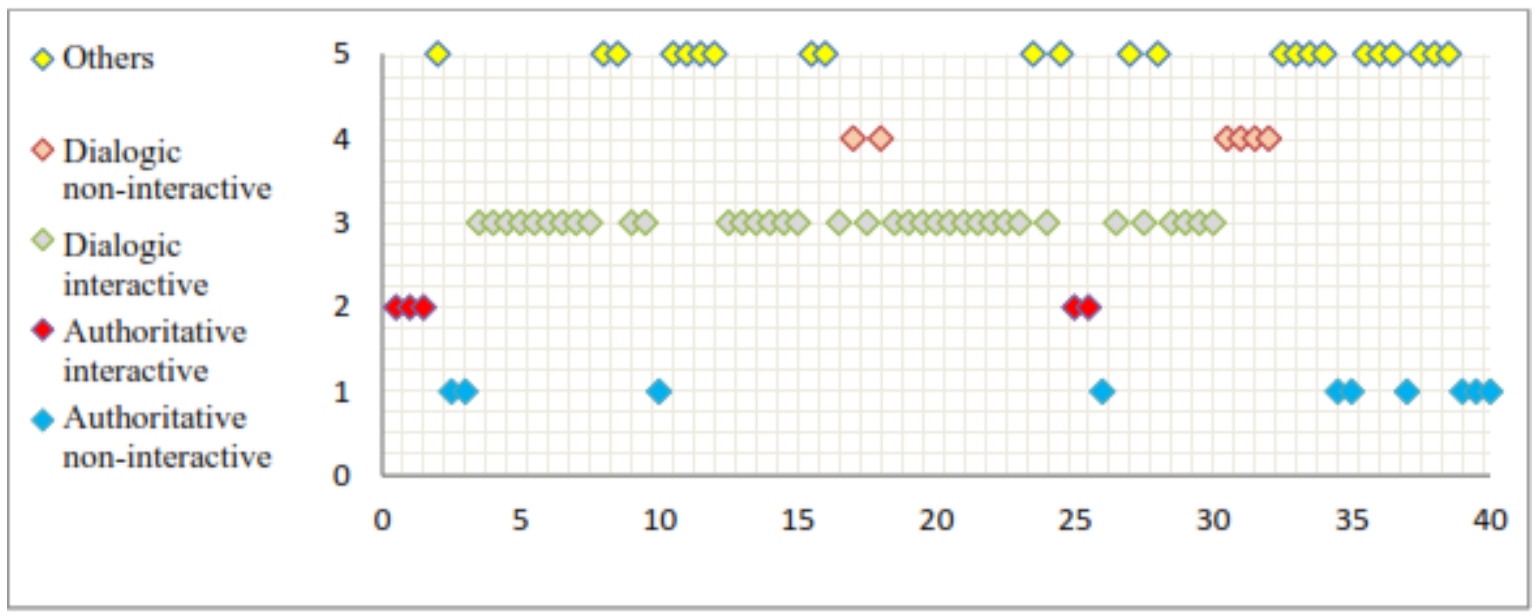

Graph 7. The graph of the analysis of the pre-service teacher Yasin's lesson video after the training program in terms of the communicative approach

As can be seen in Graph 7, the pre-service teacher used all the communicative approaches in his lesson. The pre-service teacher Yasin started the lesson in an authoritative interactive manner by asking the question "Which objects are there in the sky?" The pre-service teacher prepared some materials before coming to the lesson such as foam, pin and pieces of paper on which the common and different characteristics of stars and planets are written. He handed out the pieces of paper to the students seated in groups. Then he explained what they would do with the materials he brought to the class in an authoritative non-interactive manner. Here, the purpose of the pre-service teacher Yasin was to elicit what the students knew about the subject and to construct the lesson through dialogues in a whole class interaction. The students discussed in groups and attached their papers on foams with pins. Meanwhile, the teacher walked across the groups and asked questions such as "What do you think?" In this section both student-student and teacher-student dialogues occurred. The dialogues occurring in this section are given below:

1. Yasin T: Everybody will discuss their opinions in the groups. Not only one or two people, is it understood, friends?

2. S.14: Please put this on the star.

3. S.8: Is the planet or the stare bigger?

4. S.13: In this way, it only reflects the light, stop stop, look only reflects the light (pointing to the planet)

5. S.15: What he described as a sphere must be a planet.

6. S.10: What are their common aspects? (start and planet)

7. S.13: It only reflects the light, look.

8. S.15: Only reflects the light (pointing to the planet)

9. S.8: He says it is the source of light.

10. S.13: What is this (bigger), I think this is a planet.

11. Yasin T: Friends, please think and come to a common decision. You can try first to agree on one characteristic.

12. Yasin T: Go on thinking and discussing for a while then we will discuss it altogether.

13.S.13: Ok, it is colder than the other objects, then which one do you think it is?

14. S.14: This must be a characteristic of the planet.

15.S.13: "It moves very fast" says this paper. 
16. S.8: I think it is the star.

17.S.13: It must be a celestial body

18. S.14: In my opinion, both of them.

19. S.12: Star; their location is not certain, star.

20. S.14: I think the common characteristic of both of them, common characteristic.

21. S.15: Look, it says "smaller", isn't the planet smaller?

22.S.13: No starts are smaller.

23. S.8: Planets are smaller.

24. S.13: Planets are larger.

25. S.15: Planets are smaller, smaller than the sun.

26. S.13: Planets are larger.

27. S.15: Let's check it.

28. Yasin Ö: Ok, wait for your other friends.

29. S.13: It is a source of energy.

30. S.10: I think this is the common characteristic of both of them.

Then the pre-service teacher asked the groups' spokespeople to summarize their discussions so that all the students in the class would learn others' opinions. Meanwhile, he used the dialogic interactive communicative approach. By attempting to elicit the points on which the groups experienced conflicts, the pre-service teachers listed the different opinions of the groups on the board. Here is given a section of the discourse having occurred between the pre-service teacher and the spokespeople of the groups:

31. Yasin T: Now let's listen what our friends thought about the characteristics of starts. If you have different opinions please explain them and their reasons to your friends. The spokesperson of the Star group please read us the characteristics of the star (While making up the groups, the pre-service teacher asked them to find a name for their groups)

32. Yasin T: This group says "They are most of the bright objects we see in the sky."

33. Students: Yes, right.

34. Yasin T: Is there any objection?

35. Students: No.

36. Yasin T: No.

37.S.5: It is in the shape of a sphere.

38. Yasin T: Your friend says it is in the shape of a sphere?

39.S.13: No, no.

40.S.14: We do not think so.

41.S.8: We don't either.

42. S.15: Yes teacher, neither do we.

43. Yasin T: What do you think then?

44. Yasin T: Those agreeing please explain why you agree and those disagreeing please explain why you disagree?

The pre-service teacher helped the students to reach an agreement within their groups first and then as a class. He listed the points on which the groups experienced some conflicts on the board and then structured his lesson around these conflicting issues. In the sections called others in the graph, the pre-service teachers continuously warned the students to respect each other's opinions. When the students did not care about these warnings, the preservice teacher warned them again and again.

Towards the end of the lesson, the pre-service teacher made the students watch a video to clarify the still conflicting points. By stopping the video when necessary, he made some explanations about the conflicting points by using the authoritative non-interactive communicative approach. After watching the video, he himself presented the scientific view by using the authoritative non-interactive approach and ended the lesson. 


\section{The communicative approaches used by the pre-service teacher Yasin in his lesson after the training program}

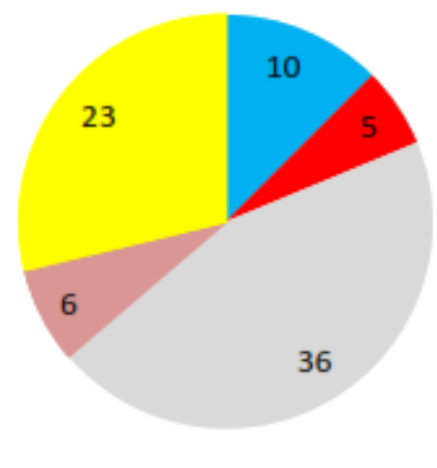

Authoritative non-interactive

Authoritative interactive

Dialogic interactive

Dialogic non-interactive

Others

Graph 8. \% graph of the analysis of the lesson video of the pre-service teacher Yasin after the training program in terms of the communicative approach

As can be seen in Graph 8, the pre-service teacher used the authoritative interactive (5\%), authoritative noninteractive (10\%), dialogic interactive (36\%) and dialogic non-interactive $(6 \%)$ communicative approaches in his lesson. After the training program, the pre-service teacher Yasin started to mind different opinions, to ask students to make explanations and reasons for their explanations, to make students discuss their opinions and to understand all these different opinions. The pre-service teacher gave chance to students to explain their viewpoints and to comment on issues and opinions emerging during the lesson. Moreover, without judging the correctness or falseness of the opinions expressed by students, he paid attention to all of them thus made it possible for the dialogue to continue.

The pre-service teacher Yasin's opinions about the communicative approach he used in his lesson after the training program

The pre-service teacher Yasin's opinions about his lesson after the training program are as follows:

"When I watched my last lesson, I realized these: Carefully listening to students and structuring the lesson around their conflicting opinions increase the dialogic interaction. For instance, if the teacher interacts with students with the sole purpose of reaching the correct answer in his/her mind, then an authoritative interaction occurs. He/she asks questions, seeks for ways of reaching the correct answer in his/her mind. In my opinion, the purpose in a dialogic interaction should be not to find the correct answer rather to seek for the false alternatives. For example, if a student says "The sun is square", then we need to persuade him/her that it is not. Moreover, in the nail example in the training program, for example. If the teacher persuades students the what they think is false on the basis of the environments where the nail becomes rusty rather than asking them the factors causing the nail to become rusty, then they can reach the truth. I think here what should be decided on is that "do we try to make students find the correct answer?" or "do we proceed over their false information?" I think if we proceed over their false information, then the dialogic interaction starts. If you remember, in my last lesson, I received that answer "both of them are in the form of a sphere". It was correct. Yet, when asked "Is there anyone having a different opinion?", one said that "we think different" and I asked them why they think different and to discuss the issue with other groups. In fact, I had already received the correct answer but the students in another group were thinking different. My first aim was to persuade these students that their opinion is false. In my last lesson, as I tried to do these, I was able to construct the dialogic interaction in my class. The class where I taught before and after the training program was very noisy. Therefore, from time to time I had to warn them to be respectful to each other's opinions and in this regard, I experienced some difficulty. I think that throughout a lesson, not only the dialogic interactive but all the other communicative approaches need to be used. The opinions elicited through the dialogic interactive communication approach should sometimes be elicited 
by means of authoritative approaches. Thus, the opinions can be better elaborated. In my opinion, a lesson should be started and continued by using the dialogic approach but the lesson should be concluded with authoritative approaches."

When the pre-service teacher Yasin's evaluations of his lesson are examined, it is seen that he pointed out that much of the lesson was instructed via the dialogic interactive communicative approach. The results of the video analysis (Graph 8) also confirmed that much of the lesson was taught by using the dialogic interactive communicative approach. The pre-service teachers' reasons for their using the authoritative and dialogic approaches in their lessons are summarized below in Table 5.

Table 5. The Reasons, According to the Pre-service Teachers, For Their Using the Authoritative and Dialogic Approaches

\begin{tabular}{|c|c|c|}
\hline $\begin{array}{l}\text { Pre-service } \\
\text { teacher }\end{array}$ & $\begin{array}{l}\text { Reasons for using the authoritative } \\
\text { approaches }\end{array}$ & $\begin{array}{l}\text { Reasons for using the dialogic } \\
\text { interactive communicative approaches }\end{array}$ \\
\hline \multirow[t]{3}{*}{ Aylin } & $\begin{array}{l}\text { - Asking closed ended question. } \\
\text { - Focusing on the correct answer } \\
\text { (knowledge). }\end{array}$ & \multirow[t]{3}{*}{$\begin{array}{l}\text { - Directing the lesson on the basis of } \\
\text { students' opinions. }\end{array}$} \\
\hline & - Ensuring classroom control. & \\
\hline & - Adhering to the lesson plan. & \\
\hline \multirow{4}{*}{ Yasin } & $\begin{array}{l}\text { - Not wanting students to express } \\
\text { and justify their opinions. } \\
\text { - Focusing on the correct answer. }\end{array}$ & $\begin{array}{l}\text { - Patiently listening to students. } \\
\text {-Focusing on the false answer rather } \\
\text { than the correct one. }\end{array}$ \\
\hline & $\begin{array}{l}\text { - Not asking open ended questions. } \\
\text { - Concern about students' nor } \\
\text { learning scientific knowledge. }\end{array}$ & \multirow[t]{3}{*}{$\begin{array}{l}\text { - Proceeding over the false opinions } \\
\text { of students to reach the correct } \\
\text { information. }\end{array}$} \\
\hline & - Ensuring classroom control. & \\
\hline & $\begin{array}{l}\text { - Not knowing the dialogic } \\
\text { approaches. }\end{array}$ & \\
\hline
\end{tabular}

\section{Discussion and Conclusion}

The findings of the current study revealed that the pre-service teachers had frequently used the authoritative approaches in their lessons before the training program. That is, the pre-service teachers mostly used the authoritative approaches by either directly presenting the scientific knowledge to their students (authoritative noninteractive) or initiating short interactions with students in order to get the correct answer in their minds (authoritative interactive). Though some different students answered the questions in some interactions, the main aim of the pre-service teachers was to receive the correct answer in their minds and after getting this answer, they finished the interaction. Pimentel and McNeill (2010) found that the lessons proceeded under the domination of teachers and with the dominant use of the question-answer-evaluation cycle. As a result, they emphasized that the internal belief systems of science teachers should be altered related to science teaching. Molinaria and Mamelia (2010) also reported that rather than the dialogic approach, classroom activities are dominated by teacher lecturing and discourse models directed to control of the interaction. Similarly, Löfgren, Schoultz, Hultman and Björklund (2013) analyzed the science classes in terms of the communicative approach and concluded that discourses are mostly dominated by the scientific definitions and stressed that the use of the dialogic interactive communicative approach should be increased in classes.

After the training program however the pre-service teachers made use of the dialogic approaches as well as the authoritative approaches. That is, the pre-service teachers also included the dialogic interactions in their lessons to 
elicit students' opinions, for students to justify and question their opinions, to generate alternative answers, to test their ideas and to compare with their prior knowledge. In the literature, the findings of Kanadlı (2012) and Akış (2012) concur with these finding of the current study.

Moreover, the pre-service teachers were asked to watch their lesson videos recorded before and after the training program and write which communicative approach they had used in their lessons and reasons for using these communicative approaches. The pre-service teachers mentioned different factors leading them to the use of the authoritative approaches. One of these factors is related to the characteristics of the questions. One of the factors leading the pre-service teachers to the use of the authoritative approaches is their asking closed ended questions and these questions' entailing single correct answers. In the literature, according to Hardman and AbdKadir (2010), teachers are generally tended to ask closed ended questions in their lessons and students' questioning knowledge and concepts on the basis of the questions directed by the teacher; thus, under the guidance of the teacher, which is believed not to do more than explanation and retention of the knowledge, was found the most common form of teacher-student interaction. Oliveira (2009) found that after a two-week training given to the teachers, the teachers started to ask twice as many questions as they had to elicit students' opinions. In this regard, changing the questions asked within the classroom is believed to result in changing communicative approach used in the class. Hackling, Simith and Murcia (2010) pointed out that the more use of open ended questions and less judging students' answer in the classroom environment promote the use of the dialogic interactive communicative approach.

Both of the pre-service teachers remarked that their attempts to ensure classroom control and focusing on the correct answer led them to the use of the authoritative approaches. One pre-service teacher stated that concern about students' not learning the scientific knowledge resulted in the use of the authoritative approaches. Thus, he/she thought that it would be appropriate to transmit the scientific knowledge to students either through lecturing (authoritative non-interactive) or by asking questions to direct students to the correct answer in his/her mind (authoritative interactive). This pre-service teacher also stated that feeling obliged to adhere to the lesson plan also led him/her towards the use of the authoritative approaches. The dialogic interactive communicative approach mostly proceeds over students' responses given to open ended questions asked by the teacher.

Students' prior knowledge, misconceptions, opinions conflicting with their friends' opinions are generally different and the aim of the teacher in using the dialogic interaction is to construct the lesson together with students by eliciting their opinions. Therefore, he/she preferred to use the authoritative approaches thinking that otherwise it would be difficult to keep up with the lesson plan. The other pre-service teacher stated that he/she used the authoritative approaches as he/she did not know the dialogic approaches.

The pre-service teachers stated that they used the dialogic interactive communicative approaches more in their lessons and explained the reasons for their using the dialogic interactive communicative approaches after the training program. One pre-service teacher stated that the factor enabling him/her to use the dialogic interactive communicative approaches was his/her constructing the lesson on the basis of students' opinions. According to Kouffeta-Menicou and Scaife (2000), when lessons are structured through dialogues, teachers ask many open ended questions to students, enabling them to get engaged in active questioning. According to Erdogan and Campell (2008), opinions of a group of students are taken through this approach and the teacher utilizes questioning to explain, detail or seek for alternative opinions and to promote thinking and reasoning. In this way, communication becomes cumulative and students are supported to collectively make sense of ideas, establish connections between ideas and explain meanings.

One pre-service teacher pointed to the importance of the teacher's patience in listening to the student in terms of elaborating students' responses. In the literature, Akpinar and Ergin (2005) note that when a student asks a question, the teacher or other students should not answer immediately rather wait for a while. In this way, during the waiting time, many students can get ready to participate in the lesson, can ask follow-up questions, can get ready to listen to each other and can become mentally more active. Moreover, as the student's self-confidence will be nurtured when he/she is carefully listened by his/her teacher and what he/she says is valued by the whole class, such behaviors should be commonly demonstrated in the class. The same pre-service teacher also stated that one of the important reasons for his/her using the dialogic interaction in his/her lesson is his/her focusing more on students' false answers than their correct answers and structuring the lesson in such a way as to lead students to the correct knowledge over their false responses. 
In light of the findings of the current study, some suggestions can be made for researchers:

- The data collected through the data collection tools in the current study were analyzed in line with the purpose of the study. Future research can look into the types of questions used by teachers and pre-service teachers in classes, students' level of understanding these questions, the waiting time set by the teacher for students to answer the questions and teachers and students' misconceptions by using the discourse analysis.

- Further research can be conducted to shed light on the effect of the communicative approach used by teachers in their classes on students' learning.

- Further research can investigate students' opinions about the communicative approach used by teachers in the class.

\section{Acknowledgments}

The current study was conducted within the context of the doctoral study completed under the supervision of Prof. Dr. Hüseyin Bağ from the Education Faculty of Pamukkale University. At the same time, the study was supported by the Scientific Projects of Pamukkale University (Project No: 2013 EĞBE 005). 


\title{
Öğretmen Adaylarının Fen Öğretiminde Kullandıkları İletişimsel Yaklaşımların Söylem Analizi
}

\begin{abstract}
Giriş
Diyalojik Öğretim

Diyalog, sadece belli bir konuda fikir alışverişi ve uzlaşma değil, aynı zamanda öğrencilerin kendi başlarına daha önceden edinemedikleri bilgileri kazanma süreci olarak da görülür (Game ve Metcalfe, 2009: 45). Diğer bir deyişle, diyalog sürecinde yaşanan yoğun sosyal etkileşim sayesinde bireyler kendilerini ve diğer katılımcıları eğitmektedirler. Dolayısıyla diyalog, pedagojik bir potansiyele sahiptir. Bu gücünü sosyal yapılandırmacı felsefenin de dayanağı olan sosyal etkileşimden almaktadır. Bu nedenle öğrenme ve öğretimin sosyo-kültürel bir yanının da olduğu düşüncesiyle, araştırmacılar 'diyalojik öğretim’ kavramını kullanmışlardır (Alexander, 2006; Nystrand, Gamoran, Kachur, Prendergast, 1997).
\end{abstract}

Alexander’a (2006) göre diyalojik öğretim, öğrencinin akıl yürütmesini ve kavramasını genişletmenin yollarını aramalıdır. Ayrıca öğrencilerin aktif hale getirilmesi de diyalojik öğretimde önemlidir. Diyalojik öğretimin anahtar özellikleri; kollektif, karşıt, destekleyici, kümülatif ve amaçlı olmasıdır (Alexander, 2006). Diyalojik öğretimdeki anahtar nokta, sınıf içi konuşmaların kümülatif bir nitelikte olması gerektiğidir. Yani, öğretmen ve öğrenciler fikir geliştirirler ve bu yolla ortaklaşa sınıf ortamında bilgiyi yapılandırılar (Mortimer ve Scott, 2000). Diyalojik öğretim, öğretmen tarafından sorulan özgün ve konuyla ilgili soruların artan kullanımı ile desteklenmektedir. Ancak burada asıl önemli olan ise, bu soruları çevreleyen iletișimin niteliğidir (Nystrand, Wu, Gamorgan, Zeiser ve Long, 2003). Genel hatlarıyla, diyalojik öğretimdeki en kritik düşünce, sınıf konuşmasında kendi bilgi dağarcıklarını oluşturmada katılımcılar olarak öğrencilere ne derece aktif roller verildiği ile ilgilidir (van Zee ve Minstrell, 1997; van Zee, Iwasyk, Kurose, Simpson ve Wild, 2001). Dolayısıyla da öğretmenlerin rolü; öğrencileri aktif olarak derse katılmaya teşvik etmek, fikir ve görüşleri uyandırmak ve mantık yürütmelerini destekleyerek, bu yolla anlamlandırma ile bilgi dağarcığı oluşturmalarına yardımcı olmaktır (Lehesvuori, 2013).

Diyalojik öğretimde sorgulama, üst seviye düşünmeyi geliştirir (Chin, 2006) ve farklı iletişsimsel yaklaşımların uygun kullanımlarını içerir ve bu nedenle de, daha fazla anlamlı öğrenim etkinliklerini beraberinde getirir (Scott ve Amettler, 2007). Bu tür etkinlikleri başlatmak ve devam ettirmekteki en önemli rol sadece bilgi kaynağı olmaya değil, aynı zamanda sınıf içi iletişimi yöneten olmaya da niyetlenen öğretmene aittir.

Öğrencilerden öğretmenlerin rehberliği olmadan öğrenmeleri beklenmemektedir (Roth, 2005). Ancak, öğretmenler öğretimi amaçlı bir şekilde yapmak isterlerse, ortaya çıkan öğrenme süreçlerinde anlamlı söylemsel stratejileri benimseyebilirler (Mercer, Dawes, Wegerif ve Sams, 2004).

Fen derslerinde diyalojik öğretim, yalnızca destekleyici ve sınıfta katılımcılar arasında karşllıklı etkileşim olarak değil, aynı zamanda öğretmenin değişik fikirler arasındaki (örneğin günlük bilgiler ve bilimsel bilgiler) diyaloğu yönetmesi olarak da anlaşılabilir (Mortimer ve Scott, 2003). Etkili bir fen öğretmeni, öğrencilere sadece fen bilimleri program içeriğini kavramalarında yardımcı olmakla kalmayacak, aynı zamanda öğrencilerin feni daha iyi anlamalarına yardımcı olacaktır. Bu yüzden Lemke'nin (1990) "fen eğitimi, öğrencileri bilimde akııı bir şekilde konuşabilen kişiler yapması gerekmektedir savı", "fen eğitimi, öğrencileri ne dediğinin farkında olan, akıcı bir şekilde konuşan ve düşünceli konuşmacılar yapmalıdır" şeklinde detaylandırılabilir (Mortimer ve Scott, 2000).

Diyalojik öğretim, daha derin öğrenme ve motivasyon için önemli özellikler içermektedir. Ancak, fen öğretiminin otoriter bir yönünün de olması gerektiği gerçeğini yeterince vurgulamakta başarısız kalmıştır. Öğrencilerin önceden var olan bilgileriyle, bilimsel bilgiler arasındaki boşluk, yalnızca diyalojik yaklaşımları kullanılarak kapatılamaz. Yani öğrenciler derslere gündelik bilgileri ile gelirler. Öğretmenin amacı, öğrencilerin gündelik dillerini iletişimsel yaklaşımı kullanarak bilimsel dile çevirmektir. Ancak bunu tamamen diyalojik yaklaşımları kullanarak yapması mümkün değildir. Ders esnasında elbetteki otoriter yaklaşımların da kullanılması gerekmektedir. Dolayısıyla, iletişimsel yaklaşım kavramı (Mortimer ve Scott, 2003) hem diyalojik hem de otoriter görüşü göz önünde tutarak fen sınıf etkileşimini tanımlamak için bir farklı bakış açısı sunar.

\section{Fen Sınıflarında Etkileşim}

Mortimer ve Scott' a (2003: 24-25) göre, fen sınıflarında öğretmen ve öğrencilerin birbirleriyle etkileşim kurarken kullandıkları kalıplar vardır. Bu kalıpların oluşturulmasındaki amaç, öğretmenin fen sınıflarında öğrencilerin öğrenmelerini desteklemek için fen derslerindeki konuşmaları yönetme yollarını betimlemek ve analiz etmektir. Bu amaca yönelik olarak da analitik bir çerçeve geliştirmişlerdir (Tablo 1). Bu çerçeve fen derslerindeki öğretmen-öğrenci etkileşimlerinin farklı yönleriyle ilgilidir ve fen öğretme etkileşimlerinin planlanması ve analizi için bir araçtır. $\mathrm{Bu}$ analitik çerçeve birbiriyle bağlantılı beş açıya dayanır. 
Tablo 1. Analitik Çerçeve: Fen Öğretim Etkileşimlerini Planlama ve Analiz İçin Araç
1. Öğretim amaçları
2. İçerik

3. İletişimsel yaklaşım
4. Söylemin desenleri
5. Öğretmen müdahaleleri

Taslağın merkezinde "iletişimsel yaklaşım" kavramı vardır ve sınıfta fikirler geliştirebilmek için öğretmenin öğrencilerle nasıl çalıştığına dair bir bakış açısı getirir. Mortimer ve Scott (2003), fen derslerinde öğrencilerin bilgilerini geliştirmek ve öğretmenlerin dili nasıl kullandıklarını nitelendirmek için iletişsimsel yaklaşım kavramını kullanmışlardır. İletişimsel yaklaşımın sınıfları, sınıf içi söylemin doğası gereği otoriter ya da diyalojik olup olmadığı ve etkileşimli ya da etkileşimsiz olup olmadığıyla ilgili olarak tanımlanmıştır (Mortimer ve Scott, 2003: 33). İletişimsel yaklaşımın sınıfları Tablo 2.'de gösterilmiştir.

Tablo 2. İletişimsel Yaklaşımın Sınıfları

\begin{tabular}{lll}
\hline & \multicolumn{1}{c}{$\begin{array}{c}\text { ETKILEŞiMLİ } \\
\text { Çok ses }\end{array}$} & \multicolumn{1}{c}{$\begin{array}{c}\text { ETKILEŞiMSiz } \\
\text { Tek Ses }\end{array}$} \\
\hline DIYYLOJiK & Diyalojik etkileşimli & Diyalojik etkileşimsiz \\
Birçok fikir & Birçok ses ve birçok fikir & Tek ses fakat birçok fikir \\
OTORİTER & Otoriter etkileşimli & Otoriter etkileşimsiz \\
Tek fikir & Birçok ses fakat tek fikir & Tek ses ve tek fikir \\
\hline
\end{tabular}

Scott ve Ametller (2007) anlamlı fen öğretiminin gerçekleşebilmesi için, diyalojik ve otoriter yönlerin her ikisini de içermesi gerektiğini vurgulamışlardır. Örneğin, eğer tartışmalar diyalojik yaklaşımla açılır ve öğrencilere farklı fikirler üzerinde çalışma olanağı sağlanırsa, bazı noktalarda da tartışmalar otoriter bir yaklaşımla kapatılmalıdır. Kapatma aşaması çok önemli olabilir (örneğin, öğrencilerin günlük bilgileriyle bilimsel bilgilerin arasındaki farkı açıklarken). Etkili öğretmenler çoğunlukla konuşma boyunca ortaya çıkan görüşleri gözden geçirir veya tartışmanın sonuna doğru geliştirilmiş açıklamaları özetler. Öğretmenlerin bu gözden geçirmesi ve bilimsel bilgiyi özetlemesi otoriter etkileşimsiz yaklaşımla elde edilir.

Fen öğretimde etkin sorgulamanın gerçekleşmesi için temel ilke, sorgulama sürecinde fikirlerin araştırılmasını, alternatif açıklamaların kıyaslanmasını, fikirlerin test edilmesi ve değerlendirilmesini, görüş ve kanıtlarla mantık yürütülmesini destekleyen tüm sınıf ve küçük grup söylemi için firsatlar içermesidir. Öğretmen ve öğrencilerin diyalojik etkileşimli iletişimsel yaklaşımı etkili bir şekilde kullanmalarını destekleyen müdahaleler ve keşifçi konuşmalarının, öğrenme süreci ve ürünü ile öğrencilerin bilişsel gelişimi üzerinde önemli ve olumlu etkilerinin olduğu belirtilmektedir (Mercer ve diğerleri, 2004).

\section{Araştırmanın Amacı}

Fen bilgisi öğretmen adaylarının fen öğretiminde kullandıkları iletişimsel yaklaşımları belirlemektir. Dolayısıyla, bu araştırma kapsamında aşağıda verilen sorulara yanıt verilecektir:

1. Eğitim öncesi ve sonrasında öğretmen adaylarının fen öğretiminde kullandıkları iletişimsel yaklaşımlar nelerdir?

2. Eğitim öncesi ve sonrasında öğretmen adaylarının derslerinde sıklıkla kullanmayı tercih ettikleri iletişimsel yaklaşım ve iletişimsel yaklaşımı kullanmalarındaki gerekçeler nelerdir? 


\section{Araştırmanın Önemi}

Araştırma-sorgulama süreci, sadece "keşfetme ve deney" olarak değil, "açıklama ve argüman” oluşturma süreci olarak da ele alınır. Araştırma-sorgulamaya dayalı öğrenme; öğrencilerin çevrelerindeki her şeyi keşfetme isteği duydukları, etraflarındaki doğal ve fiziksel dünyayı sağlam gerekçelerle açıklamalarda bulunarak güçlü argümanlar kurdukları, fen bilimlerinden heyecan duyan ve değerini bilen bireyler olarak yetiştikleri, kısacası birer bilim insanı gibi yaparak-yaşayarak-düşünerek bilgiyi kendi zihninde oluşturduğu öğrenci merkezli bir öğrenme yaklaşımıdır. Öğretmenler, öğrencilerinin fikirlerini rahatça ifade edebildikleri, düşüncelerini farklı gerekçelerle destekleyebildikleri ve arkadaşlarının iddialarını çürütmek amacıyla karşıt argümanlar geliştirebildikleri diyaloglar içerisinde yer almalarını sağlar. Karşıt argümanları içeren yazılı veya sözlü tartışmalarda öğretmenler, öğrencilerinin geçerli verilere dayalı oluşturdukları iddiaları, haklı gerekçelerle sundukları tartışmalarda yönlendirici ve rehber rolü üstlenir (MEB, 2013).

Sorgulamaya dayalı fen eğitiminin anahtar ilkelerinden biri, sorgulama sürecinin öğrencilerin kanıt ve fikirlerle mantık yürütmelerinin sağlanmasının yanında, soru ve görüşlerinin incelenmesi için olanaklar içermesi gerektiğidir. $\mathrm{Bu}$ yüzden fen dersini öğretme ve öğrenme, öğretmenin sorgulamayı destekleyen söylemi yönetmesini ve öğrencilerin öğrenmelerini sağlayan konuşmalara katılmalarını içermektedir (Hackling, Smith ve Murcia, 2010). Ancak yapılan araştırmalara göre, uygulanan programlar bu sorgulama görüşlerine dayalı olsa da, olması gerekenden daha fazla otoriter söylemler kullanılmakta ve öğretmen yönlendirmeleriyle sorgulamalar engellenmektedir (Lehesvuori, Ratinen, Kulhomaki, Lappi ve Viiri, 2011; Ryder ve Leach, 2006). Bunun nedenini, Pimentel ve McNeill (2013) fen derslerine yönelik olarak yapmış oldukları çalışmada, öğretmenlerin kendilerinin yönettiği sınıf içi tartışmaların ideal olmadığına inandıkları halde, otoriter bir tutum sergilemeye devam ettiklerini belirtmektedirler. Yani aslında öğretmenler otoriter yaklaşımları kullanmamaları gerektiğini bilmelerine karşın, derslerinde otoriter yaklaşımlara sıkça yer vermekte oldukları belirlenmiştir. Mercer, Dawes ve Staarman (2009) göre ise, otoriter yaklaşımların fen derslerinde sıkça kullanılma nedeni, diyalojik yaklaşımlara göre nispeten daha kolay bulunmasıdır.

Öğretmenlerin, öğrencilerinin fikirlerini rahatça ifade edebildikleri, düşüncelerini farklı gerekçelerle destekleyebildikleri ve arkadaşlarının iddialarını çürütmek amacıyla karşıt argümanlar geliştirebildikleri diyaloglar içerisinde yer almaları için diyalojik yaklaşımları kullanmaları gerekmektedir. Ancak ülkemizde, fen bilimleri öğretmenlerinin fen öğretiminde kullandıkları söylemlere ilişkin sınırlı sayıda araştırma bulunmasına rağmen (Akış, 2012; Kanadlı ve Sağlam, 2012), uluslararası literatür incelendiğinde fen öğretim programlarında yer alan konuların öğretiminde öğretmenlerin derslerinde kullanmış oldukları söylemlere ilişkin çok sayıda çalışmanın olduğu görülmektedir (Mortimer ve Scott, 2003; Lehesvuori, Viiri ve Puttonen, 2010; Monilari, Mameli ve Grisci, 2012; Pimentel ve McNeil, 2013; Löfgren, Schoultz, Hultman ve Björklund, 2013; Lehesvuori, Viiri ve Puttonen, 2011). Ayrıca yurt içi alan yazın incelendiğinde, öğretmenlerin argümantasyon uygulamalarında (Demirbağ, 2017) ve bilimin doğasını öğrencilere kazandırabilmek için (Kaya vd., 2016) diyalojik söylemleri kullanmaları gerektiğine değinen çalışmalar mevcutken, geleceğin öğretmeni olan öğretmen adaylarına diyalojik öğretim ve iletişimsel yaklaşımın tanıtılması ve derslerinde kullanabilme durumlarını yansıtan hiçbir çalışmaya rastlanmamıştır. Ancak fen bilimleri öğretmenlerinin sınıf içi söylemini geliştirmeye yönelik hazırlanan bir mesleki gelişim programının etkililiğinin incelendiği bir çalışmaya rastlanmıştır (Kanadlı ve Sağlam, 2016). Bu bağlamda, öğretmen adaylarına diyalojik öğretim ve iletişimsel yaklaşım kavramı tanıtılarak bu yönde farkındalıklarının arttırılması amaçlanmış ve araştırmacı tarafından öğretmen adayları ile yedi hafta süren bir eğitim gerçekleştirilmiştir. Bu çalışma çerçevesinde tanıtılan iletişimsel yaklaşımlardan diyalojik yaklaşımların da fen öğretmenlerince derslerde kullanılmasının; araştırma-sorgulamaya dayalı fen öğretiminin gerçekleştirilmesinde, bilimin doğasını öğrencilere kazandırmada, argümantasyon ve STEM uygulamalarında kullanılması (Ortman, 2015) açısından literatüre katkı sağlayacağı düşünülmektedir.

\section{Yöntem}

\section{Araştırma Modeli}

$\mathrm{Bu}$ çalışma, fen derslerinde iletişimsel yaklaşım konusunda son sınıf öğretmen adaylarının mesleki gelişimlerinin desteklenmesi amacıyla gerçekleştirilen doktora tez çalışması kapsamında yürütülmüş̧ür. Bu makalede yer verilen araştırmanın amacı ise; iki öğretmen adayının fen öğretiminde kullandıkları iletişimsel 
yaklaşımların belirlenmesidir. Araştırmanın amacı doğrusunda sınıf içi iletişimsel yaklaşımları belirlemek için söylem analizi yöntemi kullanılmıştır. Söylem analizi için ise katılımcı gruptan seçilen öğretmenlerin dersleri örnek olaylar olarak kullanılmıştır.

\section{Araştırmanın Çalışma Grubu}

Pamukkale Üniversitesi Eğitim Fakültesi İlköğretim Bölümü Fen Bilgisi Öğretmenliği Anabilim Dalı’nda, 2012-2013 eğitim-öğretim yılı bahar döneminde bir dönem boyunca "Öğretmenlik Uygulaması" dersini alan ve gönüllü olarak araştırmaya katılan son sınıf 2 öğretmen adayı çalışma kapsamında yer almıştır. Öğretmen adayları çalı̧̧madan önce iletişimsel yaklaşım kavramıyla hiç karşılaşmamış olup, ilk kez çalışmada karşılaşmışlardır. Çalışmaya çok fazla gönüllü öğretmen adayı katılmış ancak eğitimleri hiç aksatmayan bir erkek ve bir kadın olmak üzere 2 öğretmen adayının verileri değerlendirilmiştir. Çalışmada katılımcıların adları takma adlar kullanılarak adlandırılmıştır. Söylem analizinde örnekleme süreci diğer araştırma tekniklerindeki örnekleme sürecinden farklıdır. Çünkü söylem analizi bir metin ya da söylemdeki kullanılan dille ilgilenmekte, diğer araştırma yöntemleri ise kişilerle ilgilenmektedir. Bir başka deyişle söylem analizinde dili kullanan kişiler değil, kullanılan dil odak noktasıdır. Bu anlamda söylem analizinde kişilere yönelik bir örnekleme yapılmamaktadır. Bu da küçük bir örneklem hacmi kullanılmasını yeterli kılmaktadır. Zira büyük bir örneklem hacmi araştırmanın analitik olarak yönetilebilirliğini zorlaştırmakta ve buna ek olarak araştırma sonuçlarına önemli katkılarda da bulunmamaktadır (Elliot, 1996'dan akt Baş ve Akturan, 2008).

\section{Veri Toplama Süreci}

Çalışmanın başında, öğretmen adaylarının derslerinde kullandıkları iletişimsel yaklaşımların belirlenmesine yönelik olarak birer dersleri videoya çekilmiştir. Bu sırada öğretmen adayları uygulama derslerinin videolara çekilme sebebinden habersizdir. Bu çekimler öğretmen adaylarının akranları tarafından yapılmıştır. Daha sonra öğretmen adaylarına diyalojik öğretim ve iletişimsel yaklaşıma yönelik farkındalık oluşturmak için 7 hafta süren bir eğitim programı geliştirilmiş ve uygulanmıştır. Öğretmen adayları haftada iki saat eğitime tabii tutulmuşlardır. Eğitimlerin genel amacı, her bir aşama sırasında (örn. teorik açıklamalar, örnekler ve uygulamalı aktiviteler) iletişimsel yaklaşımın varlığını ve uygulamasını sürdürmektir. Eğitimler haftalara göre şu şekilde verilmiştir:

Öğretmen adaylarının büyük bir çoğunluğu güncellenen 2013 fen bilimleri dersi öğretim programından haberdar olmadıklarını belirttikleri için eğitimlerin ilk haftasında öncelikle programın tanıtılması ve ögretmenöğrenci rollerine değinilerek başlanmasına karar verilmiştir. İkinci hafta Vygotsky'nin bakış açısına göre feni öğretme ve feni öğrenme ve diyalojik öğretimin nasıl olabileceğine yönelik sunum hazırlanarak öğretmen adaylarıyla paylaşılmıştır. Üçüncü hafta öğretmen adaylarına Mortimer ve Scott'un (2003) geliştirmiş olduğu iletişimsel yaklaşımın teorik çerçevesi tanıtılmıştır. Dördüncü hafta öğretmen adaylarına Mortimer ve Scott'un (2003) hazırlamış olduğu her bir iletişimsel yaklaşımın ders dizisi içinde kullanımına yönelik örnek fen ders tasarısı sunulmuştur (paslanma konusu). Özellikle bu ders tasarısında her bir iletişimsel yaklaşımın ders dizileri boyunca öğretmen tarafından nasıl kullanıldığını ve öğrencilerin gündelik dilinin bilimsel dile nasıl çevrildiğini görmek mümkündür. Beşinci hafta öğretmenin sınıfta farklı iletişimsel yaklaşımları nasıl kullandığını ve özellikle diyalojik etkileşimli iletişimsel yaklaşımın daha net anlaşılmasına yönelik olarak "An Investigation of Dialogic Teaching in Science Classrooms" (Scott, Ametler, Staarman ve Mercer, 2007) adlı makaledeki episode kısımları Türkçeleştirilerek öğretmen adaylarına sunulmuştur. Bu makalede öğretmen diyalojik etkileşimi başlatmak için kavram karikatürü kullanmıştır. Dolayısıyla ders tasarılarında sınıf tartışmasını başlatmak ve geliştirmekte argümantasyon, tahmin et-gözle-açıkla, kavram karikatürleri, senaryo vb. kullanılabileceği belirtilmiş ve öğretmen adaylarıyla örnek uygulamalar yapılmıştır. Altıncı hafta yine öğretmenin sınıfta farklı iletişimsel yaklaşımları nasıl kullanabileceğini ve özellikle tüm iletişimsel yaklaşımlar arasındaki gerilimin anlaşılabilmesi için "The Tension Between Authoritative and Dialogic Discourse: A Fundemental Characterist of Meaning Making Interactions in High School Science Lessons (Scott ve diğerleri, 2006)" adlı makale Türkçeleştirilmiş ve episode kısımları öğretmen adaylarına sunulmuştur. Yedinci hafta öğretmen adaylarına üretken sınıf söyleminin nasıl olabileceğine dair üretken sınıf söylemine ilişkin sunum hazırlanmış ve bu sunum öğretmen adaylarıyla paylaşılmıştır (Uçak, 2014).

Eğitimlerin sonunda öğretmen adaylarından okuldaki fen bilimleri öğretmeninin o hafta işleyeceği konuya yönelik olarak onlara verdiği kazanımlar doğrultusunda ders tasarıları yapmaları istenmiştir. Katılımcı öğretmen adayları derslerini 40 dakika üzerinden planlayıp, uygulama okulunda işlemişlerdir. Eğitimlerden sonra öğretmen 
adaylarının işlemiş oldukları derslerin video kaydı yine akranları tarafından yapılmıştır. Video kayıtlarının bitiminden sonra öğretmen adaylarının eğitim öncesi ve sonrası ders video kayıtlarını izleyerek dersinde sıklıkla kullandığını düşündüğü iletişimsel yaklaşımı ve bu yaklaşımı kullanmalarındaki gerekçelere ilişkin dönüt yazmaları istenmiştir. Böylece bu iki öğretmen adayının sınıflarında sıklıkla kullanmış oldukları iletişimsel yaklaşımı ve bu iletişimsel yaklaşımı kullanma gerekçeleri belirlenmiştir.

\section{Verilerin Çözümlenmesi ve Analizi}

Araştırmadaki temel veri kaynağı çalışmadaki öğretmen adaylarının derslerinin sesli ve görüntülü video kayıtlarıdır. Süreç içerisinde kaydedilen bu videolar MAXQDA 11 paket programı kullanılarak söylem analizine tabi tutulmuştur. Her bir öğretmenin derslerinden elde edilen diyaloglardaki ne kadar süre ile hangi iletişimsel yaklaşımı kullandığı hesaplanarak öğretmen adayının genel eğilimi ortaya çıkarılmaya çalışılmıştır. Yazılı transkriptten sonra konuşmalar video görüntüleri ile tekrar okunmuş ve var olan kodlar üzerinden kodlamalar yapılmıştır.

Öğretmen adaylarının derslerine ait video kayıtları söylem analizi kullanarak konuyla ilgili ders dizileri boyunca etkileşim sürecini tanımlayarak yapılmıştır. Söylem analizi, yazılı metinlerin ayrıntılı bir dilbilimsel analize tabi tutulduğu nitel bir analiz türüdür (Özdemir, 2010). Söylem analizi söylemi esas almakta ve günlük cümlelerin veya metinlerin söylenme bağlamında incelenmesine dayanmaktadır. Söylem analizi içerik analizinden farklı olarak kelimelerin, cümlelerin, ifadelerin gerçek anlamlarını bulmaya çalışır (Baş ve Akturan, 2008).

Videolara ilişkin veri analizinin kodları Mortimer ve Scott (2003) tarafından tanımlanan iletişimsel yaklaşımdan elde edilmiş olup, aşağıdaki gibidir:

- Otoriter etkileşimli: Soru-cevap rutinlerinin olduğu, alternatif ve farklı görüşlerin ele alınmasına çok az yer verilerek, çoğunlukla değerlendirilen öğrenci cevapları ortaya çıkmaktadır.

- Diyalojik etkileşimli: Öğrencilerin görüşleri (örneğin gündelik bilgiler) kasten hiçbir değerlendirici bakış olmaksızın araştırılır ve onlardan faydalanılır. Öğretmen belli bir bakış açısı aramaz, daha çok amaçlı bir şekilde öğrencilerin bakış açılarını ortaya çıkarmaya çalışır ve birbirine uymayan görüşler üzerinde çalışır.

- Otoriter etkileşimsiz: Öğretmen net bir şekilde, çoğunlukla ders anlatım yoluyla, bilimsel bilgiyi sunar.

- Diyalojik etkileşimsiz: Öğretmen, daha önceden öğrencilerin bakış açılarından ifade edilmiş zıt fikirleri kullanarak bilimsel görüşe doğru ilerler. Bu arada öğrencilerle etkileşime girmez.

Her bir öğretmen adayına ilişkin video kayıtları izlenerek söylem analizi yoluyla yukarıda belirtilmiş olan kodlar doğrultusunda analiz yapılmıştır. Bu kodlamalar doğrultusunda öğretmen adaylarının ders boyunca kullanmış oldukları iletişimsel yaklaşımı görmek mümkün olmuştur. Yazılı metin haline getirilmiş olan video dökümleri ile de öğretmen adaylarının kullandıkları iletişımsel yaklaşım kesitleri örneklendirilmiştir.

Veriler analiz edilirken, rastgele seçilen bir öğretmen adayına ait video kaydı nitel araştırma deneyimine sahip, iletişimsel yaklaşım eğitimlerine katılan ikinci araştırmacı tarafından da kodlanarak uyuşum katsayısı hesaplanmıştır. Sonra iki araştırmacı tarafından yapılan analizler arasında tutarlık incelemesi yapmak üzere bir araya gelinmiş, farklı ele alınan kodlamalar tartışılarak uzlaşma sağlanmıştır. Uyuşum katsayısını hesaplamada;

$\mathrm{P}=[\mathrm{Na} / \mathrm{Na}+\mathrm{Nd}]$ x 100 (Miles ve Huberman, 1994: 69) formülünden yararlanılmıştır. Kodlayıcılar arasındaki uyuşum katsayısı hesaplanmış ve Tablo 3'de sunulmuştur.

Tablo 3. İki Kodlayıcı Arası Güvenirlik

\begin{tabular}{cccc}
\hline Veri Seti & $\begin{array}{c}\text { Uyuşum } \\
\text { miktarı }(\mathrm{Na})\end{array}$ & $\begin{array}{c}\text { Uyuşmazlık Miktarı } \\
(\mathrm{Nd})\end{array}$ & Uyuşum Yüzdesi (P) \\
\hline $\begin{array}{c}\text { Öğretmen adayı } \\
\text { Aylin'in video kaydı }\end{array}$ & 73 & 7 & 91,25 \\
\hline
\end{tabular}

Aynı zamanda, öğretmen adaylarından çalışmanın bitiminden sonra kendi videolarını izlemeleri ve kullandıkları iletişimsel yaklaşımları söylem analizi ile raporlamaları istenmiştir. Ayrıca çalışma dışından alanda uzman bir öğretim üyesinden de rasgele seçilen bir öğretmen adayının videosunu izlemesi ve dilsel anlamda 
güvenirlilik çalışması sonucunda oluşturulan söylem analizi raporunu incelemesi ve dönütler vermesi istenmiştir. Videolara ilişkin veri analizinin kodları Mortimer ve Scott (2003) tarafından tanımlanan iletişimsel yaklaşımdan elde edilmiştir. Söylem analizi de bu kodlara göre yapılmıştır. Bu kodlamalar ilişkin görüş birliği sağlanmış olup, öğretmen-öğrenci, öğrenci-öğrenci diyaloglarının rahatlıkla bu kategorilerde toplandığı tespit edilmiştir. Dolayısıyla araştırma bulguları benzer ortamlarda rahatlıkla test edilebilir. Bu bağlamda çalışmanın tüm aşamaları hakkında ayrıntılı bilgi verilmeye çalışılarak çalışmanın geçerliliği sağlanmıştır.

\section{Bulgular}

\section{Öğretmen Adaylarının Eğitim Öncesi ve Eğitim Sonrası Derslerinde Kullandıkları İletişimsel Yaklaşım}

Her iki öğretmen adayının da eğitim öncesi ve eğitim sonrası dersleri analiz edildiğinde benzer iletişimsel yaklaşımları kullandıkları görülmüştür. Aşağıda öğretmen adayı Aylin'in eğitim öncesi sınıf-içi uygulamaları örneklendirilmiștir.

\section{Öğretmen adayı Aylin'in eğitim öncesi sınıf içi uygulamaları}

Öğretmen adayı Aylin öğretmenlik uygulamasını 6. sınıf öğrencilerin fen derslerinde gerçekleştirmiştir. Öğretmen adayı eğitim öncesi dersinde "kanın yapısı" konusunu işlemiştir. Aşağıda öğretmen adayı Aylin'in eğitim öncesi ders videosunun iletişimsel yaklaşım açısından analizinin grafiği (Grafik 1) görülmektedir.

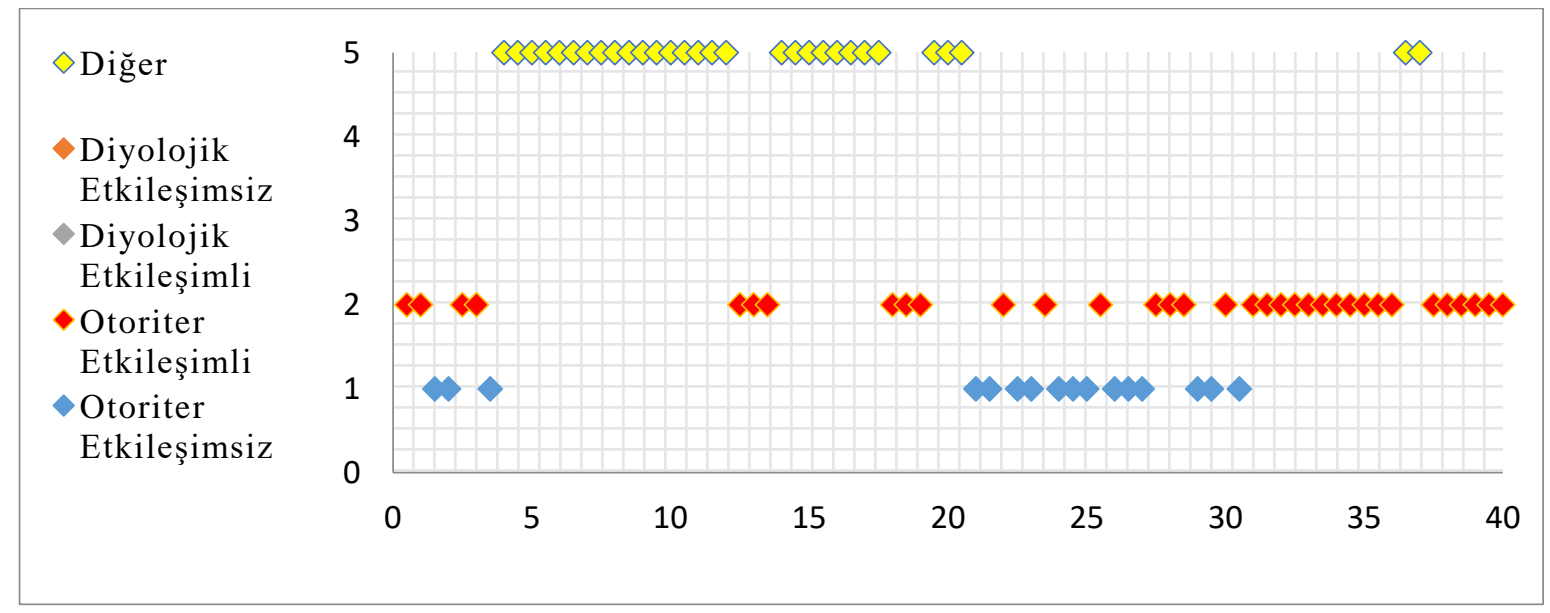

Grafik 1. Öğretmen adayı Aylin'in eğitim öncesi ders videosunun iletişimsel yaklaşım açısından analiz grafiği

* Grafikte yatay eksen dakika olarak zamanı, dikey eksen ise iletişimsel yaklaşımı gösterir. Diğer olarak adlandırılan kısımdan kasıt ise; öğretmenin duyuru niteliğindeki konuşmaları, bilgisayar ya da projektörü açması, öğrencilerin mikroskoptan görüntü incelemeleri, video izlemeleri gibi iletişimin olmadığı durumlar ya da ders dışı söylemler.

Grafik 1. incelendiğinde, öğretmen adayının dersinin iletişimsel yaklaşım açısından otoriter etkileşimli ve otoriter etkileşimsiz geçtiği görülmektedir. Öğretmen adayı Aylin dersine otoriter etkileşimli iletişimsel yaklaşımı kullanarak başlamış olup, dersinde kullanmış olduğu söylemden bir kesit aşağıdaki gibidir:

1. Aylin Ö: Şimdi biraz hatırlayalım bizim büyük küçük kan dolaşımı organlarımız nelerdi bana söyleyebilir misiniz? Hangi organlarımız vardı evet?

2. Ö.12: Kalp

3. Aylin Ö: Kalp vardı evet.

4. Ö.22: Damar.

5. Aylin Ö: Damar vardı. Evet, evet sen? 
6. Ö.17: Kan

7. Aylin Ö: Kan vard1.

8. Ö.23: Böbrek.

9. Aylin Ö: Böbreğimiz vardı böbreğimizden geçiyordu.

10. Ö.12: Akciğer.

11. Aylin Ö: Akciğerlerimiz vardı.

12. Ö.22: Atardamar.

13. Aylin Ö: Atardamarımız vardı.

14. Ö.23: Toplardamar.

15. Aylin Ö: Toplardamarımız vardı.

16. Ö.12: Kılcal damar.

17. Aylin Ö: Kılcal damarlarımız vardı.

18. Ö.17: Kılcal damar.

19. Aylin Ö: Söylemiştik evet kılcal damarlarımız vardı.

20. Ö. 27: Öğretmenim

21. Aylin Ö: Evet Mehmet.

22. Ö. 27: Aort vardı.

23. Aylin Ö: Aort vardı.

24. Ö. 27: Akciğer atardamarı vardı.

25. Aylin Ö: Akciğer atardamarı vardı.

26. Aylin Ö: Evet şimdi biz geçen haftaki dersimizde damarlarımızın görevlerini kalpten nasıl kanı götürüp getirdiğini, akciğerlerimizde temizlendiğini tekrar vücudumuz dolaşıp kirlendiğini öğrendik. Bugünkü dersimizde de hani biz hatırlıyor musunuz ilk dersimizde böyle vücudumuzu bir şehir merkezine işte bir şehir merkezindeki yollar olduğunu söylemiştik. Şimdi damarlarımızı gördük. Peki damarlarımızın içerisinde ilgili organa temizlenmesini ya da kirlenmesini komut veren yapı neydi ve ne yapıyordu? Bunu yani damarlarımızın içerisinde bizim ne dolaşıyor da temizleniyor, kirleniyor, besin, oksijen taşıyor? Kan çocuklar değil mi?

Öğretmen adayı Aylin bu söylem kesitinde 26. diyaloğa kadar öğrencilere sorduğu kapalı uçlu bir soruya cevaplar almaktadır. Öğretmen adayı Aylin'in 3., 5., 7., 11., 13., 15., 17., 19., 23. ve 25. diyaloglarda öğrencilerin verdiği her cevabı onayladığı görülmektedir. 26. diyalogda ise otoriter etkileşimsiz iletişimsel yaklaşımı kullanarak dersine devam etmiştir.

Öğretmen adayı sınıfa getirmiş olduğu iki mikroskobu ayarlamıştır. Daha sonra her öğrenciden sessiz bir şekilde masaya gelip görüntüye bakıp defterine çizmelerini istemiş̧ir. Sınıf kalabalık ve iki mikroskop olduğu için uzun zaman almıştır. $\mathrm{O}$ arada öğretmen ve öğrenciler arasında öğretmenin komutları dışında hiçbir iletişim olmadığ 1 için bu kısımlar (5-13 dakikalar arası) diğer bölümü adı altında analiz edilmiştir.

Dersin devam eden aşamalarında öğretmen adayı öğrencilere alyuvar, akyuvar ve kan pulcukları ile ilgili kapalı uçlu sorular sorarak otoriter etkileşimli iletişimsel yaklaşımı kullanarak dersini bitiriyor. Öğretmen adayı Aylin'in kullanmış olduğu iletişimsel yaklaşım yüzde olarak pasta grafiği (Grafik 2) üzerinde gösterilmiş̧tir. 


\section{Öğretmen adayı Aylin'in eğitim öncesi dersinde kullandığı iletişimsel yaklaşım}

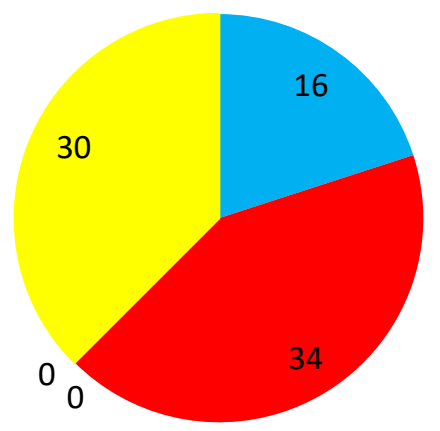

- Otoriter etkileşimsiz

- Otoriter etkileşimli

- Diyalojik etkileşimli

Diyalojik etkileşimsiz

Diğer

Grafik 2. Öğretmen adayı Aylin'in eğitim öncesi ders videosunun iletişimsel yaklaşım açısından analizinin \% grafiği

Grafik 2 incelendiğinde, öğretmen adayı eğitim öncesi dersinde otoriter etkileşimli (\%34) ve otoriter etkileşimsiz (\%16) iletişimsel yaklaşımı kullanmıştır. Öğretmen adayı Aylin’in eğitim öncesindeki dersi iletişimsel yaklaşım açısından değerlendirildiğinde dersinin büyük bir çoğunluğunda otoriter etkileşimli iletişimsel yaklaşımı kullandığ1 görülmektedir. Yani dersin büyük bir çoğunluğunda öğretmen söyleminin çoğu başlatmakarşılık-değerlendirme değişimlerinden oluşmaktadır ve bunların çoğu öğretmenin kafasındaki doğru cevabı almaya yönelik sorular olup, öğrencinin verdiği kısa cevabı değerlendirdiği geleneksel niteliktedir.

\section{Öğretmen adayı Aylin'in eğitim öncesi dersinde kullandığı iletişimsel yaklaşıma ilişkin görüşleri}

Öğretmen adayı Aylin'den eğitim öncesi işlemiş olduğu dersinin videosunu izleyip dersinde sıklıkla kullandığını düşündüğü iletişimsel yaklaşımı ve bu yaklaşımı kullanmasındaki gerekçelere ilişkin dönüt yazması istenmiştir. Öğretmen adayının eğitim öncesi dersine ilişkin dönütleri şu şekildedir:

"Dersin genelinde otoriter etkileşimli iletişimsel yaklaşımı kullanmışım. Çünkü daha çok sorular ve onlardan gelen cevaplar doğrultusunda dersi yürüttüm. Bu sorular kapalı uçlu bilgiye dayalı sorulardl. Herhangi bir sorgulama içermiyordu. Sınıf kontrolünü sağlamak amacıyla da otoriter etkileşimsiz iletişimsel yaklaşımı kullanmışım. Bir de videoyu izlediğimde ögrrencilere mikroskopta görüntü göstermiştim. Her ne kadar tahminlerini almaya ve gördüklerini çizdirmeye çalışsam da derste öğrencilere verimli olamamışım. Yani görüntüye bak çiz demişim ancak öğrenci konu hakkında hiçbir bilgisi olmadı̆̆ için görüntüleri çizememiş. Hatta birkaç ögrenci anlamadığım şeyi nasıl çizebilirim ki? demiş. Çünkü ben sadece hazırladığım plana ve bu plan doğrultusundaki soruları baz almışım. Amacım planımı uygulamak olmuş. Öğrencinin bu plan dahilinde konuyu öğrenip ögrrenmediğine odaklanmamışım. Sürekli parmak kaldıran ögrrencileri kaldırarak birkaç ögrenciden doğru cevabı alarak planımı sürdürmüşüm. Aslında diğer öğrencilere söz hakkl verip tartıştırabilirmişim. Ama dediğim gibi amacım planımı uygulamak ve doğruyu buldurmak olmuş. Bunu yapabilmek için de dolayısılla çoğunlukla otoriter etkileşimli iletişimsel yaklaşımı kullanmışım.

Öğretmen adayı Aylin'in dersine yönelik değerlendirmelerine bakıldığında, dersini çoğunlukla otoriter etkileşimli bulduğuna dikkat çekmiştir. Yapılan video analizi bulgularına göre de (Grafik 2) öğretmen adayı Aylin'in dersinde çoğunlukla otoriter etkileşimli iletişimsel yaklaşımı kullandığı görülmüştür. 


\section{Öğretmen adayı Aylin'in eğitim sonrası sınıf içi uygulamaları}

Öğretmen adayı Aylin'in eğitimler sonrasında işlemiş olduğu ders eğitim öncesi ile aynı gruptur. Öğretmen adayı eğitimler sonrasında dersinde "ses yalıtımı" konusunu işlemiştir. Aşă̆ı̆da öğretmen adayı Aylin'in eğitim sonrası ders videosunun iletişimsel yaklaşım açısından analizinin grafiği (Grafik 3) görülmektedir.

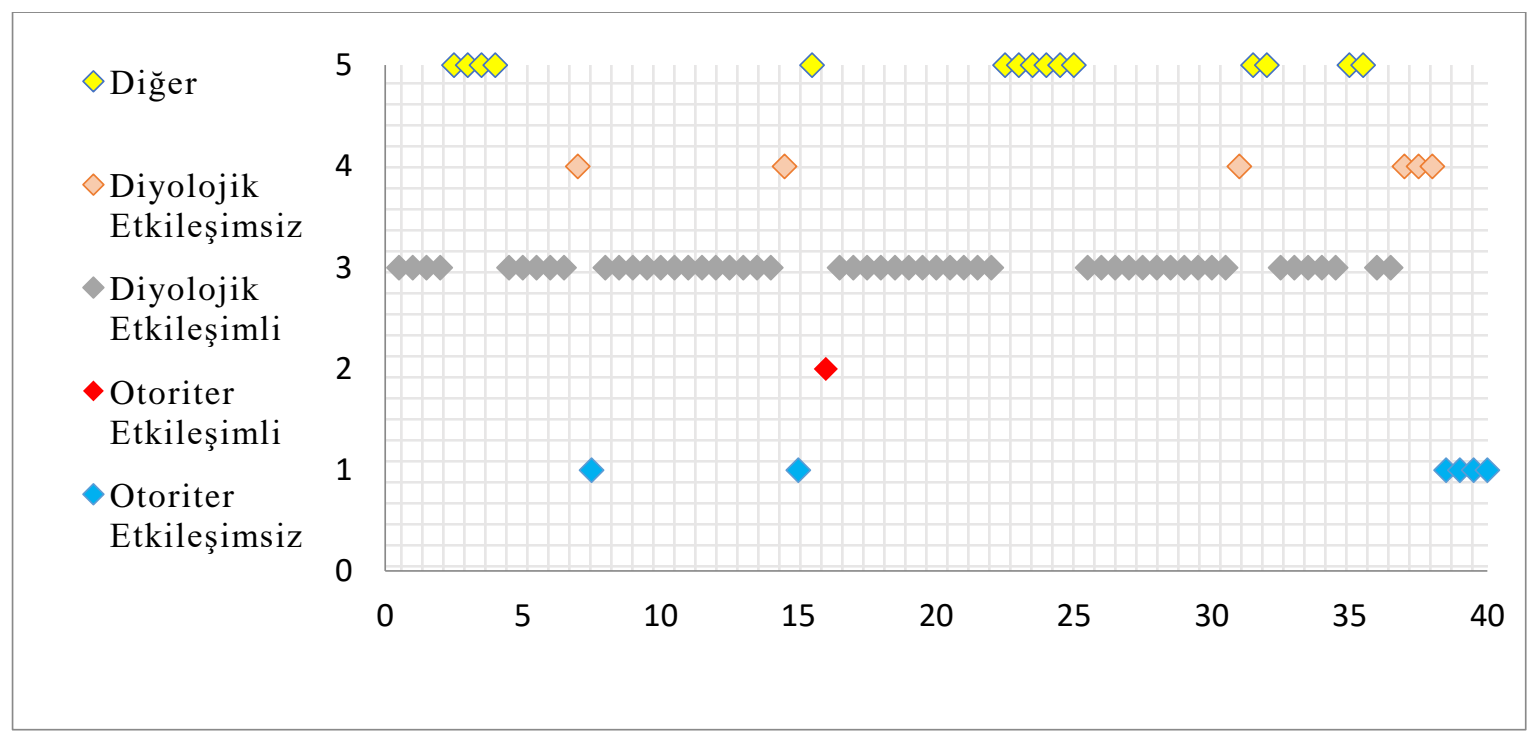

Grafik 3. Öğretmen adayı Aylin'in eğitim sonrası ders videosunun iletişimsel yaklaşım açısından analiz grafiği

Öğretmen adayı Aylin öğrencilerin sesle ilgili neler bildiklerini öğrenmek için dersine sorularla başlıyor ve diyalojik etkileşimli iletişimsel yaklaşımı kullanıyor. Dersin 3.-4. dakikaları diğer olarak adlandırılan kısımda öğretmen adayı bilgisayarda kavram karikatürü açıyor ve her öğrenciden sessizce kavram karikatürlerini okumalarını istiyor. Daha sonra bu kavram karikatüründeki dört karakterden hangisinin düşüncesine katılıp katılmadıklarını sorgulamaya başlıyor. Bu sorgulama esnasında diyalojik etkileşimli iletişimsel yaklaşımı kullanıyor. Dersin akışında ara sıra diyologları toparlayarak diyalojik etkileşimsiz iletişimsel yaklaşımı kullanıyor. Grafik 3'de görülen 15. dakikada diğer olarak analiz edilen kısımda öğrencileri gruplara ayırıyor ve otoriter etkileşimli iletişimsel yaklaşımı kullanarak dersini sürdürüyor.

Öğretmen adayı Aylin sınıfa gelmeden önce kutuların içine farklı maddeler koymuştur. Gruplara kutuları dağıttıktan sonra öğrencilerden kutuların içinde hangi maddelerin olduğunu sormuştur. Aşağıda diyalojik etkileşimli iletişimsel yaklaşıma ilişkin söylem kesiti yer almaktadır:

1. Aylin Ö: Şimdi biz bu deneyimizi neden yapıyoruz sizce?

2. Ö.16: Öğretmenim hangisi daha iyi yalıtır diye.

3. Aylin Ö: Hangisi daha iyi yalıtır diye yapıyoruz. Peki hadi bakalım tahmin edelim. Sizce?

4. Ö.16: En iyisi yumurta kolisi.

5. Aylin Ö: Size göre hangisi daha iyi yalıtır, evet siz ne düşünüyorsunuz?

6. Ö. 27: Yumurta kolisi.

7. Aylin Ö: Ama hangisine göre yumurta kolisi daha iyi yalıtır?

8. Ö.27: Köpüğe göre daha fazla.

9. Aylin Ö: Yumurta kolisi köpüğe göre daha iyi yalıtır diyor arkadaşınız. Arkadaşımızın düşüncesine katılan var mi?

10. Ö.1: Ben kat1liyorum.

11. Aylin Ö: Katılmayan var mı? 
12. Ö.5: Bence temizlik bezi.

13. Aylin Ö: Şu an yumurta kolisi ve köpük hakkında konuşuyoruz.

14. Ö.5: H111 yumurta kolisi bence.

15. Aylin Ö: Hayır öğretmenim ben buna katılmıyorum ben başka bir şey düşünüyorum çünkü diyen evet...

16. Ö.38: Öğretmenim köpük daha iyi yalıtır. Çünkü onların arasında boşluk olduğu için.

17. Ö.20: Yumurta kolisinin içinde de boşluk var ama.

18. Ö.38: Daha iyi yalıtmaz mı köpük?

19. Ö.20: Yumurta kolisinin içinde de boşluk var.

20. Aylin Ö: Yumurta kolisinin içinde de boşluk var ama diyor arkadaşınız. Siz arkadaşınızın düşüncesi ile ilgili ne söylemek istersiniz? Bir tanesi köpükte boşluk var bu yüzden daha iyi yalıtır dedi, diğeri yumurta kolisinde de boşluk var ama dedi.

21. Aylin Ö: Evet Aylin.

22. Ö.16: Bence de öğretmenim yumurta kolisi daha iyi yalıtır. Çünkü öğretmenim hatta bir tane deneyde de vardi.

23. Aylin Ö: Nasıl bir deneydi Aylin anlatır mısın bize biraz?

24. Ö.16: Öğretmenim bir tane kutunun içine saati koydular ve yumurta kolisini de koydular sonra öğretmenim kutuyu kapattıklarında dışarıdan saatin sesi gelmedi.

25. Aylin Ö: Peki biz neden yumurta kolisi seçmiş olabiliriz? Neden yumurta kolisi?

26. Ö.5: Öğretmenim bence kutu daha şey çünkü yumurta kolisi ince.

27. Aylin Ö: İncelik etkilidir diyorsun. Peki neden yumurta kolisi dedin ama?

28. Ö.5: Bilmem.

29. Aylin Ö: Neden yumurta kolisi? Evet Mehmet sen ne düşünüyorsun?

30. Ö.28: Yumurta kolisinin iç kısımları ve göçmüş kısımları var. Bu kısımlar tek başına ses yalıtımı sağlayabilen bir tasarımdır ve genellikle binaların içinde çatılarda falan kullanılabilir.

31. Aylin Ö: Peki bu dik ve içine göçmüş kısım ne gibi fayda sağlıyor bize 1sı yalıtımı ve ses yalitıminda?

32. Ö.28: Dik kısımlar sesi biraz daha düşürürken, göçük kısımlar sesin diğer taraftan gitmesini önlüyor. $\mathrm{Bu}$ sayede hem sesin dişarı çıkması hem de sesin içeri girmesi önleniyor.

33. Aylin Ö: Mehmet'e katılan var mı?

34. Ö.16: Bence de öğretmenim Mehmet doğru söylüyor. Evet onun tasarımından dolayı.

Öğretmen adayı Aylin kutulardan çıkan malzemeleri dikkate alarak deneyi neden yaptıkları hususunda öğrencilerin tahminlerini almıştır. Öğrencilerden alternatif fikirler istemekte ve hiçbir değerlendirmede bulunmadan öğrencilerden arkadaşlarının fikirlerine katılıp katılmadığını sorgulamaktadır. Öğretmen adayı Aylin öğrenci cevaplarına tarafsız geri dönütler vermektedir. Ayrıca öğrencilerden fikirlerini açıklamalarını ve gerekçelendirmelerini istemektedir. Diğer malzemeler için de diyalojik etkileşimli iletişimsel yaklaşımı kullanarak dersini sürdürmüştür.

Öğretmen adayı Aylin, öğrencilerden tahminlerini alıp bu tahminleri tahtaya sıralamıştır. Öğrencilerin gündelik bilgilerini adım adım bilimsel bilgilere dönüştürmeye çalışmaktadır. Dersin sonunda deneyi yaparak tahminleri ile bulgularını karşılaş̧ırmıştır. 
35. Aylin Ö: Tahmin etmiştiniz acaba tahminleriniz doğru mu, yanlış mı? Deney esnasında isterseniz not alabilirsiniz karşılaştırmak için.

Öğretmen adayı Aylin önce gruplara deney malzemeleri verip sırayla kutuların içindeki saat sesine odaklanmalarını ve hangi malzemelerin sesi daha iyi yalıttığını belirtmelerini istemiştir. Doğru sıralamayı yapan grup olsa da direk doğruyu onaylayıp geçmektense, tüm sınıfın doğruya ulaşması için deneyi tekrarlamaktadır. En önde ortadaki öğrenci masasında tüm deneyi tekrarlayarak kutulardan gelen sesleri dikkatle dinlemelerini istemiştir. Aşağıda söylemden alınan bir verilmiştir:

36. Aylin Ö: Kutu boşken dinliyoruz önce dinlesin herkes. Şimdi önce kutuya temizlik bezi koyacağım. Dinliyoruz. Herkes duyuyor mu? Şimdi pamuğu deniyorum. Önce temizlik bezini denedim şimdi pamuğu deniyorum.

37. Öğrenciler: Pamuk.

38. Aylin Ö: Sonuç olarak ne dedik?

39. Öğrenciler: Pamuk.

40. Aylin Ö: Peki şimdi kimler tahmin sonuçlarını değiştiriyor şimdi?

41. Grup 1: Biz.

42. Grup 3: Biz.

43. Aylin Ö: Şunları eliyorum (tahtadaki yazılanlar üzerinde eleme yapıyor.)

44. Aylin Ö: İki tane seçeneğe indirdik değil mi? Şimdi pamuk temizlik bezinden daha iyi peki temizlik bezi neyden daha iyi demiştiniz?

45. Ö.9: Pamuk.

46. Ö.5: Öğretmenim.

47. Ö.38: Yumurta kolisi.

48. Aylin Ö: Yumurta kolisi şimdi temizlik beziyle yumurta kolisini deneyelim mi?

49. Öğrenciler: Evet.

50. Aylin Ö: Yumurta kolisi, köpük yani straforu deneyelim. Şimdi köpük ikisi de aynı şey.

51. Ö.5: Öğretmenim bence yumurta kolisi strafordan daha az yalıtır.

52. Aylin Ö: Tamam deneyelim Zülal'in başka bir fikri var. Diyor ki köpük yumurta kolisinden daha iyi bunu deneyebiliriz. Yumurta kolisi ve strafor. Şimdi önce straforu koyuyorum. Yerleştirdim kutuyu kapattım. Strafor koydum. Dinliyoruz değil mi?

53. Öğrenciler: Evet.

Öğretmen adayı Aylin, öğrencilerin çelişkiye düştüğünü fark etmiş ve çelişkiye düştükleri noktada doğru olanı onaylamaktansa farklı düşündükleri noktada deneyi tekrarlamıştır ve sorgulamasına devam etmiştir. Öğretmen adayı değerlendirmede bulunmadan, öğrencilerin aynı fikirde olup olmadıklarını ve farklı düşüncede olanların düşüncelerini ortaya çıkarmalarına teşvik etmiştir.

54. Aylin Ö: Önce straforu yapıyoruz. Bakın bir dakika dinleyin. Şimdi yumurta kolisi için yapıcam. Yumurta kolisi olduğunu düşünüyorsun.

55. Aylin Ö: Anladığım kadarıyla Zülal fikrini değiştirdi ve ne düşünüyorsun Zülal?

56. Ö.5: Öğretmenim ilk başta bundan daha az geliyordu.

57. Aylin Ö: Bir dakika Zülal'i dinleyelim. Zülal bir şey söylüyor. Zülal'in önceki tahmini neydi? Zülal?

58. Ö.5: Strafor.

59. Aylin Ö: Strafor daha iyi yalıtır demişti ama şimdi diyor ki... 
60. Ö.5: Yumurta kolisi.

61. Aylin Ö: Peki siz ne düşünüyorsunuz? Onunla hem fikir misiniz?

62. Öğenciler: Evet öğretmenim biz de katılıyoruz.

63. Aylin Ö: Tekrarlayalım mı çocuklar?

64. Öğrenciler: Hayır öğretmenim.

Öğretmen adayı öğrencilerin çelişkiye düştüğünü noktaları açığa çıkarmış ve öğrencilerin diyaloglar yoluyla kendi kendilerine anlamalarına yardımcı olmuştur. Bunları sağlarken de diyalojik etkileşimli iletişimsel yaklaşımı kullanmıştır. Öğretmen adayı öğrencilerin söylemiş oldukları diyalogları toparlayarak diyalojik etkileşimsiz iletişimsel yaklaşımı kullanarak dersine devam etmiştir.

Aylin Ö: Peki tamam Zülal fikrini değiş̧irdi. Yaptığımız deney sonucunda fikrini değiştirdi. Son olarak sizler şunları söylediniz. Tahtadan sizin en son söyledikleriniz üzerinde mutahabık kaldığınız bulgular nelerdi? En çok yalıtkandan en az yalıtkana doğru şöyle bir sıralama oluşturdunuz: Pamuk, temizlik bezi, yumurta kolisi, köpük, şişe. Yumurta kolisi ve köpük arasında ilk başta bir ilişki kuramadınız. Hangisinin daha iyi olduğuyla ilgili çelişki yaşadığınız için deneyimizi tekrarladık. Tekrarladıktan sonra ise ilişki kurabildiniz ve sıralama yaptınız. Köpükle straforu farklı maddeler olarak kullanmışsınız. Ancak aynı diye düzeltmiştik.

Aşağıda öğretmen adayının öğrencilerin görüşleri doğrultusunda tahtada yaptığı sıralama görülmektedir.

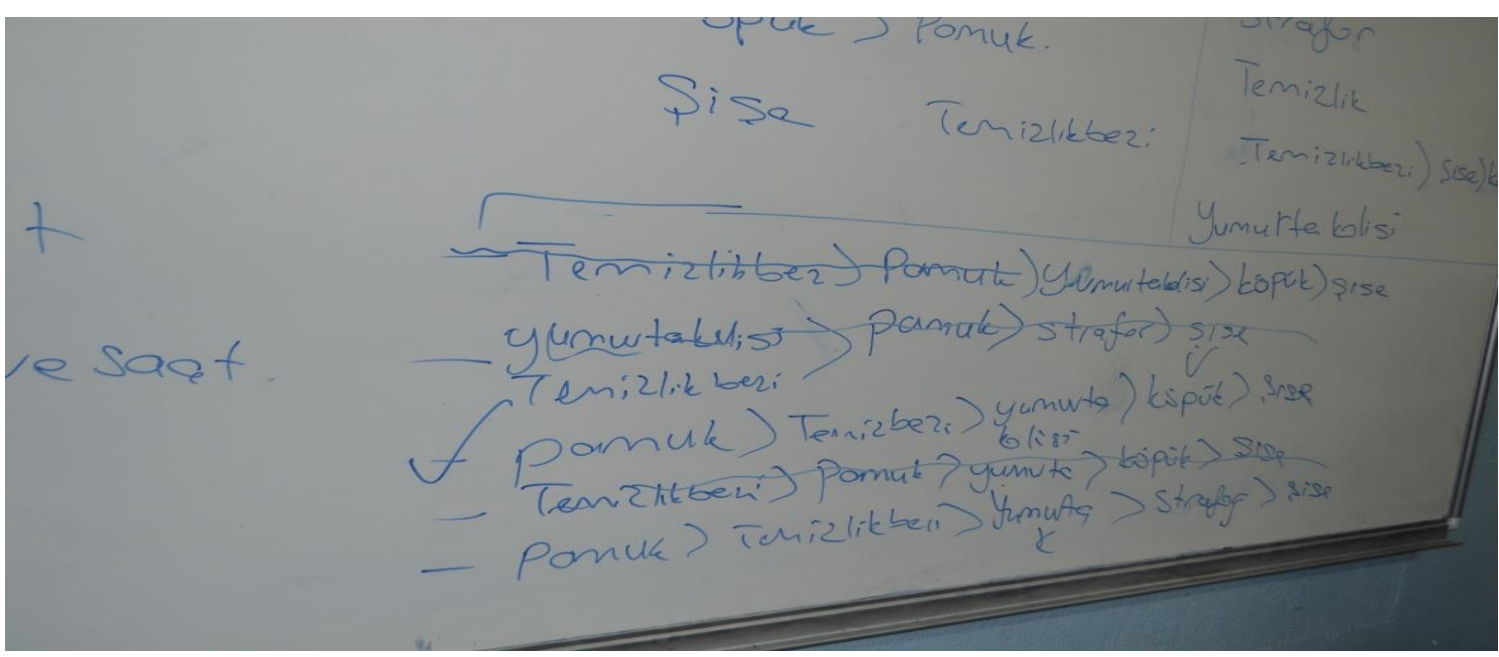

Öğretmen adayı dersinin sonunda öğrencilere bilimsel bakışı kendisi sunarak otoriter etkileșimsiz olarak dersini bitirmiştir. Öğretmen adayının kullanmış olduğu iletişimsel yaklaşım yüzde olarak pasta grafiği (Grafik 4) üzerinde gösterilmiştir. 


\section{Öğretmen adayı Aylin'in eğitim sonrası dersinde kullandığı iletişimsel yaklaşım}

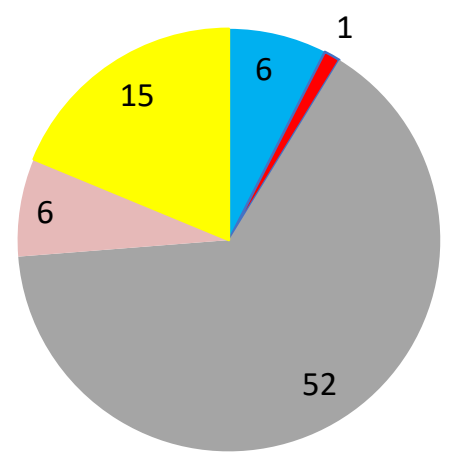

- Otoriter etkileşimsiz

—Otoriter etkileşimli

Diyalojik etkileşimli

Diyalojik etkileşimsiz

Diğger

Grafik 4. Öğretmen adayı Aylin'in eğitim sonrası ders videosunun iletişimsel yaklaşım açısından analizin \% grafiği

Grafik 4. incelendiğinde, öğretmen adayının dersinde otoriter etkileşimli (\%1), otoriter etkileşimsiz (\%6), diyalojik etkileşimli (\%52) ve diyalojik etkileşimsiz iletişimsel yaklaşımı (\%6) kullandığı görülmektedir. Öğretmen adayı Aylin'in eğitim sonrası iletişimsel yaklaşım açısından dersinin büyük çoğunluğunun diyalojik etkileşimli olarak geçtiği görülmektedir. Öğretmen adayı Aylin eğitim sonrasında farklı fikirleri önemseyen, öğrencilerin açıklamalarına gerekçe isteyen, fikirleri tartıştıran ve anlamaya çalışan bir role sahip olmuştur. Öğretmen adayı öğrencilere bakış açılarını ifade etmeleri ve ders esnasında ortaya çıkan konu ve düşünceler hakkında yorum yapmaları için şans vermektedir. Ayrıca öğrencilerin düşüncelerinin doğru ya da yanlış olmasını değerlendirmeden, bütün düşünceleri dikkate alıp, diyaloğun devam etmesine firsat vermiştir.

\section{Öğretmen adayı Aylin'in eğitim sonrası dersinde kullandığı iletişimsel yaklaşıma ilişkin görüşleri}

Öğretmen adayının eğitim sonrası dersine ilişkin dönütleri şu şekildedir:

“Aslında önemli olan seçilen iletişimsel yaklaşımın öğrencilerin düşüncelerini ortaya çıkarabilecek şekilde etkili ve anlamlı kullanılabilmesidir. Ele alınan konunun ve kazanımların doğrultusunda ögrencileri heyecanlandırarak onlarda merak ve istek uyandıran iletişimsel yaklaşımın seçilmesi önemlidir. Ancak otoriter yaklaşımlarla tüm bunları sağlamak bence mümkün değildir. Dolayısıyla diyalojik yaklaşımları da kullanmak zorundayız. Son dersimde bu şekilde düşünmeye başladığım için diyalojik yaklaşımları kullandı̆̆ımı düşünüyorum. Ayrıca diyaloglar yoluyla ögrencilerin düşünceleri üzerinden dersinize devam ettiğinizde yapmış olduğunuz plana tabii olmanız mümkün değil. Çünkü öğrencilerin soruları üzerinden dersinizi yürütüyorsunuz. Ayrıca son ders planımı hazırlarken açıkçası daha çok zaman harcadım, daha çok araştırma yaptım, daha çok düşündüm. Ne sorular gelebilir hani bununla ilgili kafa yordum. Hazırlığı ben bu şekilde yaptım. Onun dışında şu etkinliği ya da bu etkinliği diye değil sorularla belki onları yönlendirmeye çalıștım. Ayrıca ögrencilerden aldığım dönüt benim için çok önemli. Eğer öğrenciler hııı ögretmenim a bu bundanmış ben şöyle şöyle düşünüyordum diyebiliyorlarsa ĕger evet ben gerçekten başarılıyım. Son dersimde zaten bu şekilde düşünmeye başladığım için çoğunlukla diyalojik etkileşimli iletişimsel yaklaşımı kullandı̆̆ımı düşünüyorum”.

Öğretmen adayı Aylin'in dersine yönelik değerlendirmelerine bakıldığında, dersinde çoğunlukla diyalojik etkileşimli iletişimsel yaklaşımı kullandığına dikkat çekmiştir. Yapılan video analizi sonucunda (Grafik 4) da, öğretmen adayının dersinde çoğunlukla diyalojik etkileşimli iletişimsel yaklaşımı kullandığı görülmektedir.

\section{Öğretmen adayı Yasin'in eğitim öncesi sınıf içi uygulamaları}

Öğretmen adayı Yasin öğretmenlik uygulamasını 7. sınıf öğrencilerin fen derslerinde gerçekleştirmiştir. Öğretmen adayı eğitim öncesi dersinde "derişik ve seyreltik çözeltiler" konusunu işlemiştir. Aşağıda öğretmen 
adayı Yasin'in eğitim öncesi ders videosunun iletişimsel yaklaşım açısından analizinin grafiği (Grafik 5) görülmektedir.

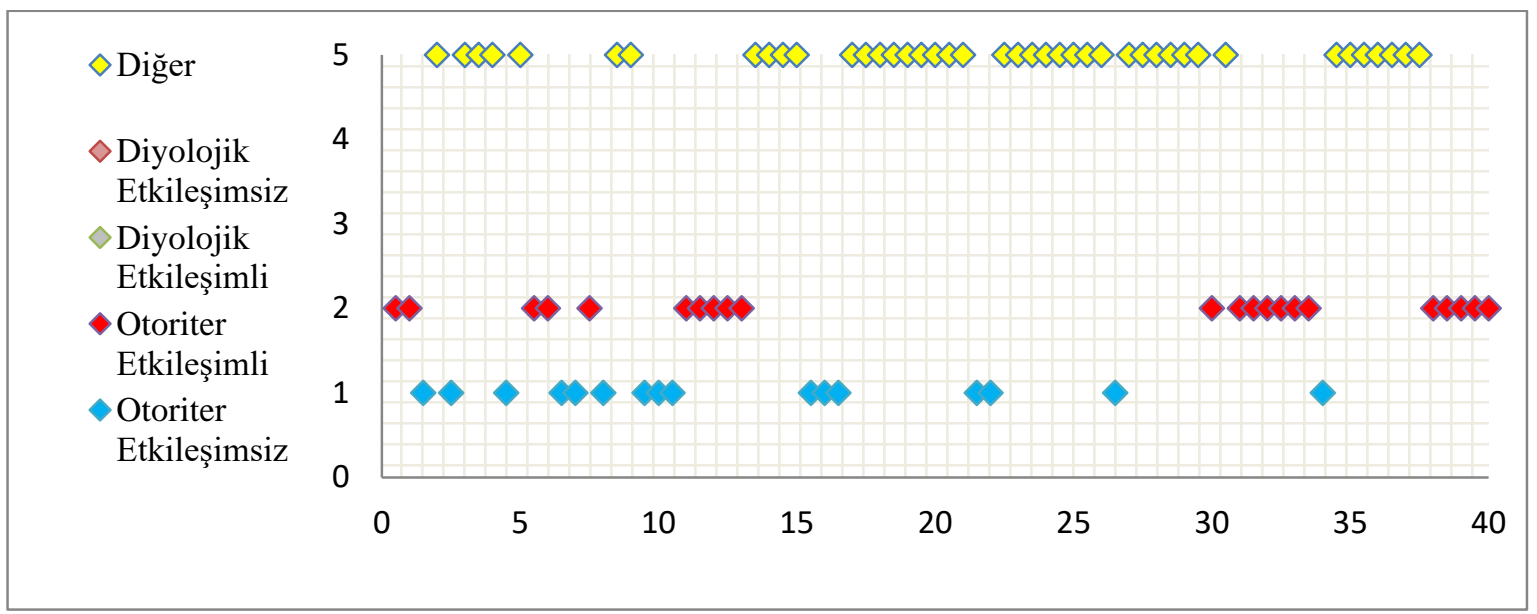

Grafik 5. Öğretmen adayı Yasin'in eğitim öncesi ders videosunun iletişimsel yaklaşım açısından analiz grafiği

Grafik 5 incelendiğinde, öğretmen adayının dersinin iletişimsel yaklaşım açısından otoriter etkileşimli ve otoriter etkileşimsiz olarak geçtĭgi görülmektedir. Öğretmen adayı Yasin dersine otoriter etkileşimli iletişimsel yaklaşımı kullanarak başlamış olup, dersinde kullanmış olduğu söylemden bir kesit aşağıdaki gibidir:

1. Yasin Ö: Peki tuzlu suda çözücü nedir?

2. Ö.10: Çözücü tuz.

3. Ö.7: Çözücü su.

4. Ö.8: Çözücü su.

5. Ö.10: Su su.

6. Ö.8: Tuzsa çözünen.

7. Yasin Ö: Tuz çözünen madde evet arkadaşlar.

8. Yasin Ö: Peki o çözeltilerde hazırladığı yani arkadaşlarımın anlattığı konuda çözeltilerde su ne kadar tuz çözebiliyordu? Ya da sürekli tuz katsak su hepsini çözebiliyor mu?

9. Ö.3: Hayır.

10. Ö.15: Hayır çözemiyor.

11. Yasin Ö: Kalıyor mesela değil mi?

12. Ö.3: Evet.

13. Yasin Ö: Size şöyle bir soru sorsam. Suyun içine biraz tuz katsak ya da birazdan daha fazla ya da ne bileyim küp şeker atsak ya da iki üç küp şeker atsak ikisini de çözer mi?

14. Ö.7: Evet.

15. Ö.8: Çözer.

16. Yasin Ö: İkisini de çözer değil mi?

17. Yasin Ö: Ama iki çözelti de aynı mıdır?

18. Öğrenciler: Hayır.

19. Ö.7: Biri daha çabuk çözünür biri az çözünür.

20. Yasin Ö: Biri daha çok çözünmüş̧ür biri daha az çözünmüştür şeklinde düzeltelim onu.

21. Ö.7: Evet.

Öğretmen adayı 1. diyalogda tuzlu suda çözücünün ne olduğunu sormakta 2., 3., 4., 5. ve 6. diyaloglarda öğrencilerden alternatif cevaplar almasına rağmen 7. diyalogda doğru cevabı onaylamaktadır. Diyalogların devam eden bölümünde de kapalı uçlu sorular sorarak (8., 13. ve 17.) doğru cevapları onaylamaktadır.

Öğretmen adayı dersin devam eden bölümlerinde gruplar şeklinde (sıraların birleştirilmesi ile grup şeklini almış) oturmuş olan öğrencilere deney malzemelerini dağıtır ve ne yapmaları gerektiğini otoriter etkileşimsiz iletişimsel yaklaşımı kullanarak anlatır. Her gruba 3 beherglas verir ve ilk beherglasa 1 küp şeker, ikincisine 2 küp 
şeker ve üçüncüsüne 3 küp şeker atmalarını ister. Daha sonra öğrenciler 3. dakikadan sonra grafikte görülen diğer olarak adlandırılan kısımda şekeri beherglas içinde karıştırırlar. Bu arada öğretmen-öğrenci ve öğrenci-öğrenci etkileşimi gerçekleşmez. Gruplardan sadece bir ya da birkaçı beherglas içerisinde şekerleri karıştırır. Diğer öğrenciler ise kendi aralarında sohbet ederler. Öğretmen adayının bu aradaki öğrencilerle tek etkileşimi sınıfta çok fazla gürültü olduğu için sessiz olmaları ve deneyi yapmaları yönünde olur.

Grafik 5.’de görülen 5-10. dakikalar arası öğretmen sıkça otoriter-etkileşimsiz iletişimsel yaklaşımı kullanmaktadır. Tahtaya derişik ve seyreltik çözeltilerin neler olduğunu anlatarak yazmış ve yazdıklarını da öğrencilerin defterlerine geçirmelerini istemiştir. Öğretmen adayı Yasin dersinin sonlarına doğru öğrencilere değerlendirme amacıyla çalışma yaprağı dağıtmış ve öğrencilerden bireysel olarak cevaplamalarını istemiştir. Dersin 37-40. dakikaları arasında da otoriter etkileşimli iletişimsel yaklaşımı kullanarak öğrencilerin cevaplarına dönüt vermiştir. Aşağıda bu dakikalar arasında kullandığı otoriter etkileşimli iletişimsel yaklaşımdan söylem kesiti verilmiştir:

22. Yasin Ö: Evet arkadaşlar birinci soruya ne dediniz?

23. Ö.19: Çözelti.

24. Yasin Ö: Çözelti doğru cevap ikinci soru.

25. Ö.15: Çözünen.

26. Yasin Ö: Adem?

27. Ö.15: Hocam çözünen.

28. Ö.8: Çözücü.

29. Ö.19: Çözücü.

30. Ö.11: Çözelti hocam.

31. Ö.8: Çözünen.

32. Ö.6: Ne çözeltisi.

33. Yasin Ö: İkinci soru çözünen. Üçüncü soru?

34. Ö.8: Çözücü.

35. Yasin Ö: Çözücü. Dördüncü soru.

36. Ö.8: Derişik.

37. Ö.18: Derişik.

38. Yasin Ö: Derişik. Beşinci soru.

39. Öğrenciler: Seyreltik

40. Yasin Ö: $\mathrm{Ne}$ ?

41. Öğrenciler: Seyreltik.

42. Yasin Ö: Tamam arkadaşlar dersimiz bitti zaten.

Öğretmen adayı Yasin, öğrencilerden çalışma yaprağındaki soruları cevaplamalarını istemektedir. Öğrencilerin vermiş oldukları cevapları değerlendirirken ikinci soruda farklı cevaplar almasına rağmen (25., 27.,28., 29., 30. ve 31. diyaloglarda) alternatif cevapları sorgulamamakta ve 35. diyalogda doğru cevabı vererek geçmektedir. Beşinci soruda öğrenciler cevap vermişlerdir (39. ve 41. diyaloglarda) ancak 42. diyalogda öğretmen adayı öğrencilerin cevaplarına yönelik herhangi bir dönüt vermemiş ve dersini bitirmiştir. 


\section{Öğretmen adayı Yasin'in eğitim öncesi dersinde kullandığı iletişimsel yaklaşım}

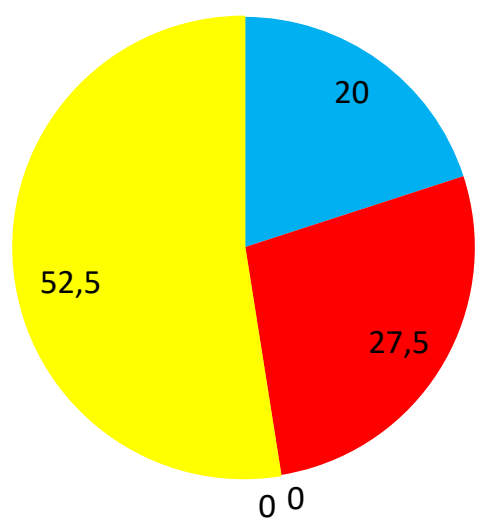

- Otoriter etkileşimsiz

- Otoriter etkileşimli

$\square$ Diyalojik etkileşimli

Diyalojik etkileşimsiz

Diğer

Grafik 6. Öğretmen adayı Yasin'in eğitim öncesi ders videosunun iletişimsel yaklaşım açısından analizinin $\%$ grafiği

Grafik 6 incelendiğinde, öğretmen adayının eğitim öncesi dersi iletişimsel yaklaşım açısından otoriter etkileşimli $(\% 27,5)$ ve otoriter etkileşimsiz $(\% 20)$ olarak geçtiği görülmüştür. Öğretmen adayı Yasin'in dersinin büyük bir çoğunluğu diğer olarak adlandırılan yapıda geçmektedir. Bu bölümler çoğunlukla öğretmen adayının sessiz kaldığı, duyuru ya da sessiz olmaları yönündeki konuşmaları, öğrencilerin çalışma yapraklarını doldurduğu, öğretmenin öğrencilerle arasında hiçbir söylem oluşturmadığı kısımlardır. Öğretmen adayı dersinin büyük bir bölümünde öğrencileri sessiz olmaları yönünde uyarmaktadır. Otoriter etkileşimsiz olarak tanımlanan bölümlerde öğretmen adayı fen bakış açısına dikkat çekerek konuyu kendisi anlatmıştır. Otoriter etkileşimli bölümlerde öğretmen söyleminin çoğu başlatma-karşılık-dönüt değişimlerinden oluşmaktadır ve bunların çoğu öğretmenin kapalı uçlu bir soru sorduğu ve öğrencinin verdiği kısa cevabı değerlendirdiği geleneksel niteliktedir. Dersin bazı bölümlerinde öğretmen adayı öğrencilerden farklı cevaplar gelmesine rağmen, yanlış cevabı göz ardı ederek doğru cevabı onaylayıp başka bir soruya geçmektedir.

\section{Öğretmen adayı Yasin'in eğitim öncesi dersinde kullandığı iletişimsel yaklaşıma ilişkin görüşleri}

Öğretmen adayının eğitim öncesi dersine ilişkin dönütleri şu şekildedir:

"İlk anlattığım derste genellikle otoriter-etkileşimli iletişimsel yaklaşımı kullanmışım. Etkileşim örüntüsü olarak da soru-cevap-değerlendirmeyi kullanmışım. İletişimsel yaklaşımı daha önceden bilmediğimiz için farkında olmadan otoriter-etkileşimli iletişimsel yaklaşımı kullandığımı düşünüyorum. Çünkü biz öğretmenlerden istenen öğrenciyi derse katmamız. Dolayısıla da öğrencileri derse katmak için sürekli soru, cevap ve değerlendirmeyi kullanıyoruz. Örneğin dersimde sürekli olarak, öğrencilerden biri cevap verdiğinde cevap doğru ise onaylamışım, yanlış ise direk doğruyu söyleyip geçmişim. Farklı öğrencilerin düşüncelerini almamışım. Hep aynı ögrencilere söz hakkı vermişim ya da ögrencilerin düşüncelerini açıklamalarını ya da gerekçelendirmelerini istememişim. Nerdeyse hiç açık uçlu soru sormamışım. Bir de ara ara otoriter-etkileşimsiz iletişimsel yaklaşımı kullandığımı düşünüyorum. Sanırım otoriter etkileşimsiz iletişimsel yaklaşımı kullanmamdaki neden sınıftaki hakimiyet, sınıfı kontrol edememe kaygısı ve bilimsel bilgiyi öğretememe kaygısı."

Öğretmen adayı Yasin'in dersine yönelik değerlendirmelerine bakıldığında, dersini çoğunlukla otoriter etkileşimli bulduğuna dikkat çekmiştir. Ayrıca ara ara otoriter-etkileşimsiz iletişimsel yaklaşımı kullandığını belirtmektedir. Yapılan video analizi sonucunda (Grafik 6) da öğretmen adayının dersinin iletişimsel yaklaşım açısından otoriter etkileşimli ve otoriter etkileşimsiz olarak geçtiği görülmektedir. 


\section{Öğretmen adayı Yasin'in eğitim sonrası sınıf içi uygulamaları}

Öğretmen adayı Yasin'in eğitimler sonrasında işlemiş olduğu ders eğitim öncesi ile aynı gruptur. Öğretmen adayı eğitimler sonrasında dersinde "yıldızlar ve gezegenlerin özellikleri” konusunu işlemiştir. Aşağıda öğretmen adayı Yasin'in eğitim sonrası ders videosunun iletişimsel yaklaşıma yönelik analizinin grafiği (Grafik 7) görülmektedir.

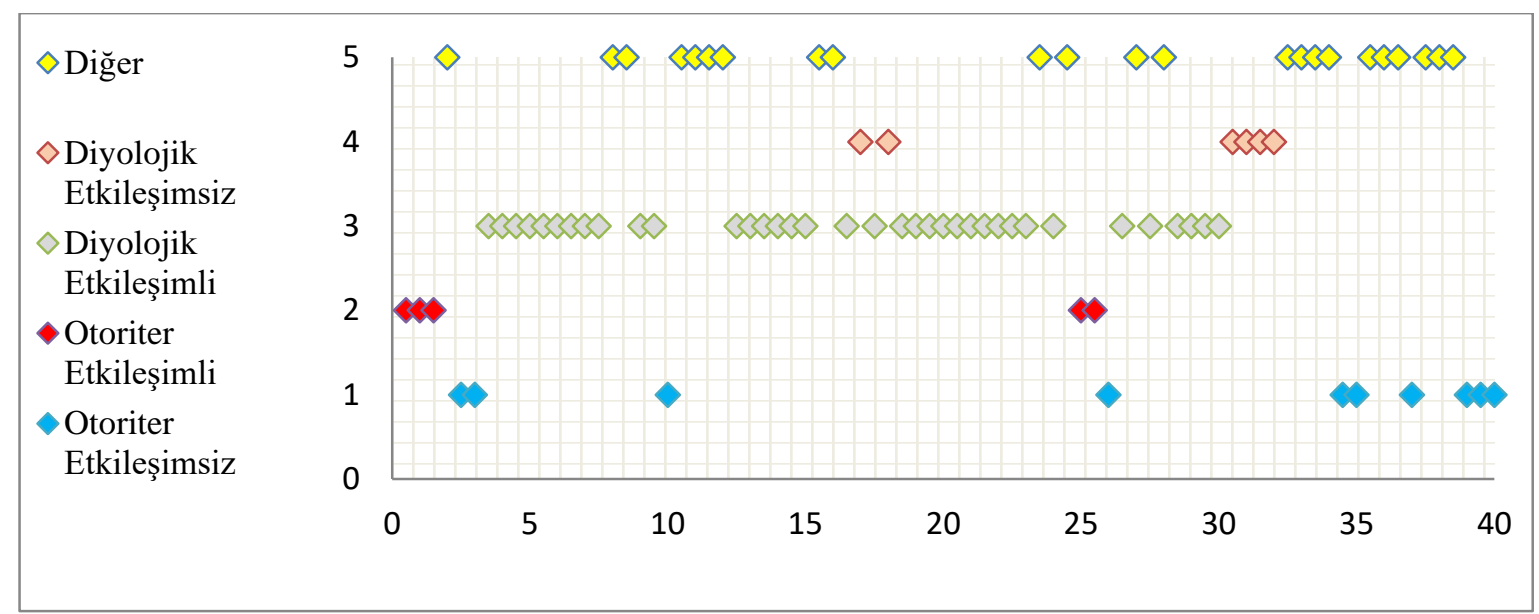

Grafik 7. Öğretmen adayı Yasin'in eğitim sonrası ders videosunun iletişimsel yaklaşım açısından analiz grafiği

Grafik 7 incelendiğinde, öğretmen adayının dersinde tüm iletişimsel yaklaşımları kullandığı görülmektedir. Öğretmen adayı Yasin dersine öğrencilerden gökyüzünde hangi cisimlerin olduğunu sorarak otoriter etkileşimli olarak başlamıştır. Öğretmen adayı dersine yönelik olarak dersten önce köpük, raptiye ve üzerinde gezegen, yıldız ve her ikisinin de ortak ve farklı özelliklerini yazan kağıtlar hazırlamıştır. Sınıfa getirdiği malzemeleri grup şeklinde oturttuğu öğrencilere dağıtmıstır. Daha sonra öğrencilere dağıttığı malzemelerle ne yapacaklarını otoriter etkileşimsiz bir biçimde anlatmıştır. Öğretmen adayı Yasin'in amacı öğrencilerin ne bildiklerini ortaya çıkarmak ve tüm sınıf etkileşimi ile dersini diyaloglar aracılığıyla yapılandırmaktır. Öğrenciler gruplar halinde tartışarak kağıtları raptiyelerle köpüklere yerleştirmiş̧lerdir. $\mathrm{Bu}$ arada öğretmen grupları dolaşarak "Evet neler düşünüyorsunuz? Sen ne düşünüyorsun?" şeklinde öğrencilere sorular sormuştur. Bu bölümde hem öğrenciöğrenci diyalojisi, hem de öğretmen-öğrenci diyalojisi gerçekleşmiştir. Bir gruba ait öğrenci-öğrenci diyalojisine yönelik söylem kesiti aşağıdaki gibidir:

1. Yasin Ö: Gruplarda herkes görüşünü söyliyecek. Sadece bir iki kişi yapmıycak tamam mı arkadaşlar?

2. Ö.14: Şunu yıldıza koysana.

3. Ö.8: Gezegen mi büyük, yıldız mı?

4. Ö.13: Böyle sadece 1şı̆̆ yansıtır dur dur bak sadece 1şı̆̆ yansıtır (gezegeni gösterek)

5. Ö.15: Küre şeklindedir dediği gezegen bence.

6. Ö.10: İkisinin ortak yönü ne acaba? (yıldız ve gezegenin)

7. Ö.13: Sadece 1şı̆̆ yansitır bak.

8. Ö.15: Sadece 1 şığı yansıtır (gezegeni gösterek)

9. Ö.8: Işı1k kaynağıdır diyor.

10. Ö.13: Bu neymiş (daha büyüktür) bence bu gezegen.

11. Yasin Ö: Arkadaşlar iyi düşünün ve ortak karar verin lütfen. Önce her bir özellik üzerinde uzlaşmaya varın isterseniz.

12. Yasin Ö: Biraz daha düşünün ve tartışın aranızda daha sonra beraber tartışalım.

13. Ö.13: Tamam diğer cisimlere göre daha soğuktur bu hangisi sizce?

14. Ö.14: Bu gezegenin özelliği olması lazım.

15. Ö.13: Çok hızlı hareket eder diyor bu kağıtta da.

16. Ö.8: Yildiz bence.

17. Ö.13: Gök cismi olmalı

18. Ö.14: Bence ikisi de. 
19. Ö.12: Yıldız zaten olacakları yer belli olmuyor yıldız

20. Ö.14: Bence ikisinin ortak özelliğidir ortak özelliğidir.

21. Ö.15: Bak daha küçük diyor, gezegen daha küçük değil mi?

22. Ö.13: Hayır ya yıldızlar daha küçük.

23. Ö.8: Gezegen küçük

24. Ö.13: Gezegen büyük

25. Ö.15: Gezegen küçük, güneşten daha küçük

26. Ö.13: Gezegen büyük

27. Ö.15: Hadi kontrol edelim ya

28. Yasin Ö: Tamam diğer arkadaşlarınızı bekleyin.

29. Ö.13: Enerji kaynağıdır.

30. Ö.10: Bence her ikisinin de ortak özelliği bu.

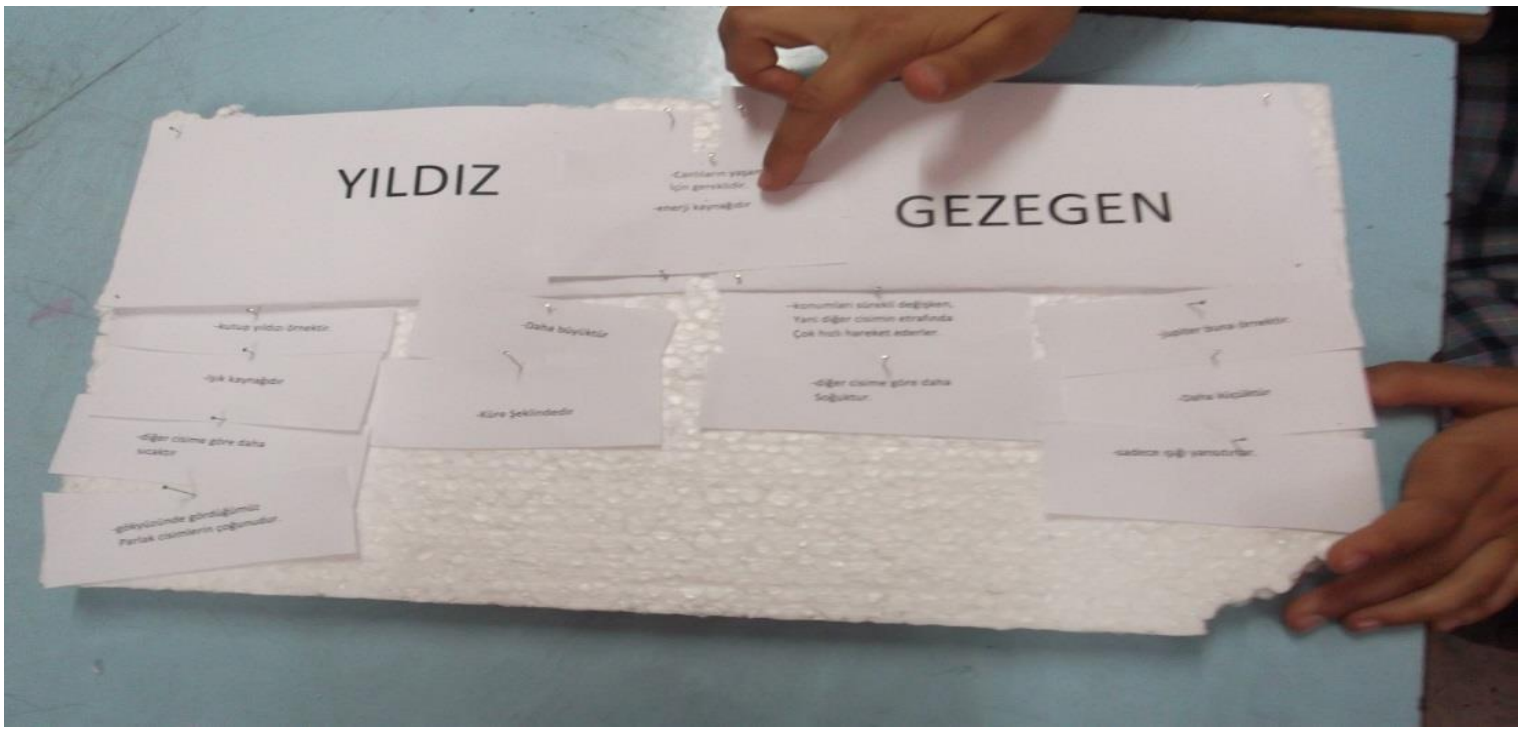

Daha sonra öğretmen adayı her gruptan bir grup sözcüsüne söz hakkı vererek grubuyla beraber oluşturdukları bilgileri tüm sınıf ile paylaşmasını istiyor. $\mathrm{Bu}$ arada diyalojik etkileşimli iletişimsel yaklaşımı kullanıyor. Öğretmen adayı grupların çelişkiye düştükleri fikirleri ortaya çıkarmaya çalışarak, gruplar arasındaki farklı düşünceleri tahtada sıralıyor. Bu sırada öğretmen adayı ile grup sözcüleri arasında oluşan söylemden bir kesit aşağıdaki gibidir:

31. Yasin Ö: Yıldız grubundaki arkadaşlarımız yıldızların özelliklerine neler yapıştırmış onu bir dinleyelim. Farklı yaptıysanız niye farklı yaptığınızı ya da niçin o şekilde düşündüğünüzü arkadaşlarınıza açıklayın. Yıldız grubunun sözcüsü lütfen bize yıldızın özelliklerini okuyabilir misin? (Öğretmen adayı grupları oluştururken her gruptan kendisine bir grup adı koymasını istemiştir)

32. Yasin Ö: Gökyüzünde gördüğümüz parlak cisimlerin çoğudur diyor, bu grup.

33. Öğrenciler: Evet, doğru.

34. Yasin Ö: İtirazı olan?

35. Öğrenciler: Yok.

36. Yasin Ö: Yok.

37. Ö.5: Küre şeklindedir.

38. Yasin Ö: Küre şeklindedir diyor arkadaşınız?

39. Ö.13: Hayır, hayır.

40. Ö.14: Biz de böyle düşünmüyoruz.

41. Ö.8: Biz de.

42. Ö.15: Evet biz de öğretmenim.

43. Yasin Ö: Ne düşünüyorsunuz?

44. Yasin Ö: Katılanlar niçin katıldığını, katılmayanlar da niçin katılmadıklarını belirtsinler lütfen? 
Öğretmen adayı önce grupların kendi aralarında, daha sonra ise birbirleri arasında görüş birliğine varmalarına yardımcı olmuştur. Grupların takıldıkları noktaları tahtada sıralayarak, bu noktalar üzerinden dersini detaylandırmıştır. Grafikte görülen diyalojik etkileşimli iletişimsel yaklaşımı kullandığı bölümlerin aralarında diğer olarak adlandırılan bölümlerde öğretmen sürekli öğrencileri birbirlerinin düşüncelerine saygılı olmaları konusunda uyarılarda bulunmaktadır. Öğrenciler bu uyarıları dikkate almadıkları için öğretmen aralarda uyarılarını tekrarlamaktadır.

Dersin sonuna doğru tüm fikirleri, çelişkiye düşülen noktaları, üzerinde fikir birliğine varılmayan noktaları hem görsel hem de açıklamalı olarak açıklığa kavuşturmak için bir video izlettirmiştir. Aralarda da videoyu durdurarak, kendisi özellikle öğrencilerin takıldıkları noktalara yönelik olarak otoriter etkileşimsiz iletişimsel yaklaşımı kullanarak açıklamalarda bulunmuştur. Video bittikten sonra tekrar bilimsel bakış açısını kendisi sunarak otoriter etkileşimsiz iletişimsel yaklaşımı kullanarak dersini sonlandırmıştır.

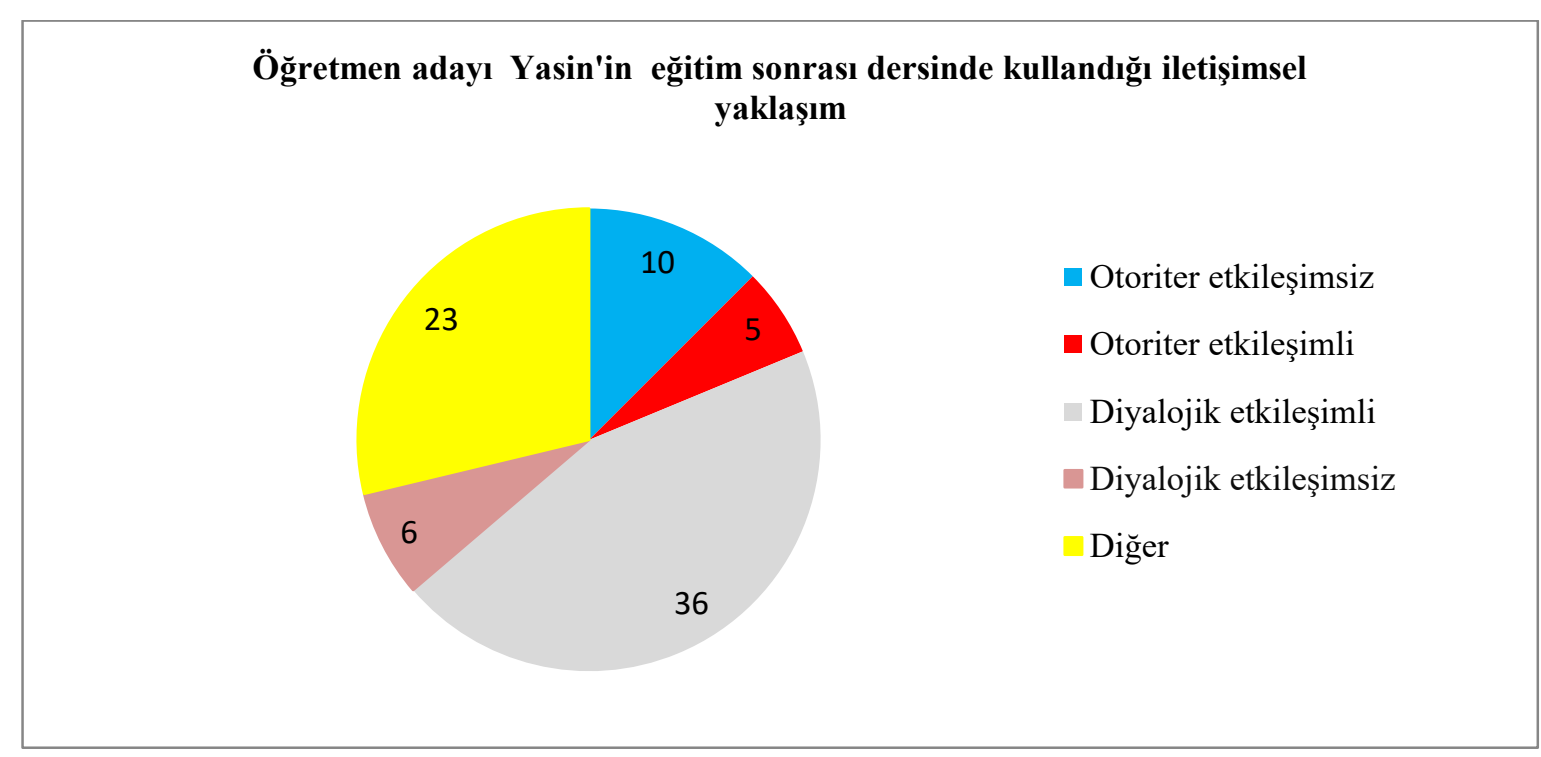

Grafik 8. Öğretmen adayı Yasin'in eğitim sonrası ders videosunun iletişimsel yaklaşım açısından analizinin $\%$ grafiği

Grafik 8 incelendiğinde, öğretmen adayı eğitim sonrası dersinde otoriter etkileşimli (\%5), otoriter etkileşimsiz (\%10), diyalojik etkileşimli (\%36) ve diyalojik etkileşimsiz (\%6) iletişimsel yaklaşımı kullanmıştır. Öğretmen adayı Yasin eğitimler sonrasında, farklı fikirleri önemseyen, öğrencilerin açıklama yapmasını isteyen, açıklamalara gerekçe isteyen, fikirleri tartıştıran ve anlamaya çalışan bir role sahip olmuştur. Öğretmen adayı öğrencilere bakış açılarını ifade etmeleri ve ders esnasında ortaya çıkan konu ve düşünceler hakkında yorum yapmaları için şans vermektedir. Ayrıca öğrencilerin düşüncelerinin doğru ya da yanlış olmasını değerlendirmeden, bütün düşünceleri dikkate alıp, diyaloğun devam etmesine firsat vermiştir.

Öğretmen adayı Yasin'in eğitim sonrası dersinde kullandığı iletişimsel yaklaşıma ilişkin görüşleri

Öğretmen adayı Yasin’in eğitim sonrası dersine ilişkin dönütleri şu şekildedir:

"Son dersimi izlediğimde şunları fark ettim: Öğrenciyi sabırlıca dinlemek, onların hataları üzerinden gitmek diyalojik etkileşimi artırır. Örneğin ögretmen kafasındaki doğru cevabı almak için etkileşime girerse otoriter etkileşimi gerçekleştirir. Soru sorar ve kafasındaki doğru cevabı almak için uğraşır. Bence diyalojik etkileşimde doğruyu bulmak değil yanlışı aramak lazım. Örneğin öğrenci güneş kare şeklindedir diyorsa onu kare olmadı̆̆ına ikna etmemiz gerekir. Ayrıca eğitimlerdeki çivi örneğinde mesela. Çivinin paslanmasına yol açan etmenler nelerdir değil, onların çivilerin hangi ortamlarda paslanacă̆ını düşündükleri ortamlar üzerinden gidip onların düşündüklerinin yanlış olduğuna ikna edersek onlar doğruya ulaşırlar. Bence burada şuna karar vermek lazım doğruyu mu buldurmaya çalışacă̆ız? Yoksa 
yanllş bildikleri üzerinden mi gidicez? Bence yanlış üzerinden gidersek diyalojik etkileşim başlar. Ben son dersimde hatırlyyorsanız her ikisi de küre şeklindedir cevabını aldım. Doğru da oydu. Ancak farkl düşünen var mı? diye sorduğumda bir grup biz farklı düşünüyoruz dedi ve neden farklı düşündükleri sorup diğer gruplarla tartışmalarını istedim. Aslında doğru cevabı almıştım ama başka bir gruptaki öğrenciler bunu farkl düşünüyorlardl. Öncelikli amacım ögrencilerin düşüncelerinin neden yanllş olduğunu onlara ikna edebilmekti. Zaten ben de son dersimde bunlarl yapmaya çalıştı̆̆ım için çoğunlukla diyalojik etkileşim olușturabildiğimi düșünüyorum. Ancak benim dersine girdiğim sinıf hem eğitim öncesinde, hem de eğitim sonrasında çok gürültülü bir sinıftı. Dolayıslyla zaman zaman sürekli birbirlerinin görüşlerine saygılı olmaları konusunda onları uyarmak zorunda kaldım ve biraz zorlandim. Bir de ders boyunca bence sadece diyalojik etkileşimli iletişimsel yaklaşımı değil tüm iletişsimsel yaklaşımları kullanabilmek lazım. Bazen diyalojik etkileșimle toplanan fikirlerin otoriter yaklașımlarla da toparlanması gerekebiliyor. $B u$ da fikirlerin havada kalmasını engelliyor. Bence bir ders diyalojik etkileşimli olarak başlayıp devam etmeli ama dersin sonunda otoriter yaklaşımlar kullanılmall."

Öğretmen adayı Yasin'in dersine yönelik değerlendirmelerine bakıldığında, iletişimsel yaklaşım açısından dersini çoğunlukla diyalojik etkileşimli bulduğuna dikkat çekmiştir. Yapılan video analizi sonucunda (Grafik 8) da dersinde sıklıkla diyalojik etkileşimli iletişimsel yaklaşımı kullandığı görülmektedir. Öğretmen adaylarının derslerinde kullanmış oldukları otoriter ve diyalojik yaklaşımları kullanmalarındaki gerekçeler özetlenerek Tablo 5. de verilmiştir.

Tablo 5. Öğretmen Adaylarına Göre Otoriter ve Diyalojik Yaklaşımları Kullanmalarındaki Gerekçeler

\begin{tabular}{|c|c|c|}
\hline $\begin{array}{l}\text { Öğretmen } \\
\text { adayı }\end{array}$ & $\begin{array}{c}\text { Otoriter yaklaşımların } \\
\text { kullanılmasındaki gerekçeler }\end{array}$ & $\begin{array}{l}\text { Diyalojik etkileşimli iletişimsel } \\
\text { yaklaşımın kullanılabilmesindeki } \\
\text { gerekçeler }\end{array}$ \\
\hline Aylin & $\begin{array}{l}\text { - Kapalı uçlu sorular sorma. } \\
\text { - Doğru cevaba (bilgiye) } \\
\text { odaklanma. }\end{array}$ & $\begin{array}{l}\text { - Diyaloglar yoluyla öğrencilerin } \\
\text { düşünceleri üzerinden derse devam } \\
\text { etme. }\end{array}$ \\
\hline & $\begin{array}{l}\text { - Sınıf kontrolünü sağlama. } \\
\text { - Ders planına tabii olma. }\end{array}$ & \\
\hline Yasin & $\begin{array}{l}\text { - Öğrencilerin düşüncelerini, } \\
\text { açıklamalarını ve } \\
\text { gerekçelendirmelerini istememe. } \\
\text { - Doğru cevaba odaklanma. } \\
\text { - Açık uçlu sorular sormama. } \\
\text { - Bilimsel bilgiyi öğreteme kaygısı. } \\
\text { - Sınıf kontrolünü sağlama. } \\
\text { - Diyalojik yaklaşımları bilmeme. }\end{array}$ & $\begin{array}{l}\text { - Öğrencileri sabırla dinleme. } \\
\text { - Doğru cevaba değil, yanlış cevaba } \\
\text { odaklanma. } \\
\text { - Öğrencilerin yanlış bilgileri } \\
\text { üzerinden derste ilerleyerek doğru } \\
\text { bilgiye ulaşma. }\end{array}$ \\
\hline
\end{tabular}

\section{Tartışma ve Sonuç}

Araştırmanın bulguları doğrultusunda, öğretmen adaylarının eğitim programından önce derslerinde sıklıkla otoriter yaklaşımları kullandıkları tespit edilmiştir. Yani, öğretmen adayları derslerinde, zaman zaman bilimsel bilgiyi öğrencilere kendileri sunarak (otoriter etkileşimsiz), zaman zaman da kafalarındaki doğru cevabı almaya yönelik olarak öğrencilerle aralarında kısa etkileşimler başlatmışlardır (otoriter etkileşimli). Her ne kadar bazı etkileşimlerde sorulara farklı öğrenciler yanıt verse de, öğretmen adaylarının amacının zihinlerindeki doğru cevabı almak olduğu, bu cevabı aldıklarında da etkileşimi bitirdikleri görülmektedir. Pimentel ve McNeill (2010) 
çalışmalarında, derslerin öğretmen hakimiyetinde ve üçlü söylem (soru-cevap-değerlendirme) şeklinde geçtiği bulgusuna ulaşmışlardır. Bu doğrultuda öğretmenlerin fen öğretimine ilişkin içsel inanç sistemlerinin değişimlerinin sağlanması gerektiğine vurgu yapmışlardır. Molinaria ve Mamelia (2010) bulguları, diyalojik söylemden ziyade, daha çok öğretmen anlatımıyla ve etkileşimi kontrol eden söylem modellerinin sınıf alıştırmalarında egemen olduğunu göstermiştir. Yine Löfgren, Schoultz, Hultman ve Björklund (2013) fen derslerini iletişimsel yaklaşım açısından analiz etmişler ve anlatım biçimlerinde bilimsel tanımların hakim olduğu bulgusuna ulaşmışlar, sınıflarda diyalojik etkileşimli iletişimsel yaklaşımın arttırılması gerektiğine vurgu yapmışlardır.

Öğretmen adaylarının eğitim programından sonra ise, derslerinde otoriter yaklaşımların yanında diyalojik yaklaşımları da kullandıkları tespit edilmiştir. Yani öğretmen adayları sınıf ortamında öğrencilerin fikirlerinin açığa çıkartılması, fikirlerinin gerekçelendirilmesi ve sorgulanması, alternatif cevaplar üretilmesi, öğrencilerin fikirleri test etmeleri ve ön fikirleri ile karşılaştırmalarına olanak sağlayan diyalojik etkileşimlere de derslerinde yer verdikleri görülmüştür. Alan yazın incelendiğinde, Kanadlı (2012) ve Akış’ın (2012) bulguları, araştırmanın bulgularını destekler niteliktedir.

Ayrıca öğretmen adaylarından eğitim öncesi ve sonrası derslerini izlemeleri ve kendilerine göre derslerinde sıklıkla kullandıkları iletişimsel yaklaşımı ve bu iletişimsel yaklaşımı kullanma gerekçelerini de yazmaları istenmiştir. Öğretmen adayları derslerinde otoriter yaklaşımları kullanmalarına neden olan çeşitli etmenler üzerinde durmuşlardır. Bu etmenlerden biri de sorulan soruların özelliğidir. Öğretmen adayları derslerinde otoriter etkileşime neden olan etmenlerden birinin, kapalı uçlu sorular sormalarına ve bu soruların da tek doğru cevap gerektirmesine bağlamışlardır. Alan yazın incelendiğinde, Hardman ve Abd-Kadir (2010) göre, öğretmenlerin ders esnasında genellikle kapalı uçlu sorular sormaya eğilimli oldukları, bilginin açıklanması ve hatırlanmasından pek de öteye gitmeyen, öğretmen sorularıyla öğrencilerin bilgi ve kavramları öğretmenin liderliğindeki sorgulaması, öğretmen-öğrenci etkileşiminin en yaygın biçimi olduğu belirtilmiştir. Oliveira (2009) çalışmasında, öğretmenlere verilen iki haftalık eğitim programının ardından, öğretmenlerin iki kat daha fazla öğrencilerin düşüncelerini açı̆̆a çıkarmaya çalışan sorular sormaya başladıkları görülmüştür. Bu bağlamda sınıf ortamında sorulan soru tiplerinin değiştirilmesinin öğretmenin kullandığı iletişimsel yaklaşımı değiştirebileceği düşünülmektedir. Hackling, Simith ve Murcia (2010) yaptıkları çalışmada, ders esnasında çok fazla açık uçlu soruların kullanılması, öğrenci cevaplarının daha az değerlendirilmesi diyalojik etkileşimli iletişimsel yaklaşımın sınıf ortamında kullanılmasına neden olduğu bulgusuna ulaşmışlardır.

Her iki öğretmen adayı da sınıf kontrolünü sağlayabilmek ve doğru cevaba odaklanmalarının onları otoriter yaklaşımları kullanmaya ittiğine değinmiştir. Bir öğretmen adayı bilimsel bilgiyi öğretememe kaygısının otoriter yaklaşımları kullanmaya ittiğini belirtmiştir. Dolayısıyla bilimsel bilgiyi ya konu anlatarak (otoriter-etkileşimsiz) ya da zihinlerindeki doğru yanıtı almaya yönelik sorular sorarak (otoriter-etkileşimli) öğrencilere aktarmanın doğru olduğunu düşünmüştür.

Bir öğretmen adayı ders planına tabii olmanın onu otoriter yaklaşımları kullanmaya ittiğine değinmiştir. Çünkü diyalojik etkileşimli iletişimsel yaklaşım öğretmenin sorduğu açık uçlu sorular doğrultusunda daha çok öğrenci fikirler üzerinde yürütülmektedir. Sınıftaki her bir öğrencinin konuyla ilgili ön bilgileri, kavram yanılgıları, arkadaşları ile çelişkiye düştükleri fikirler vb. birbirinden farklıdır ve öğretmenin diyalojik etkileşimde temel amacı, öğrencilerin düşüncelerini ya da fikirlerini açı̆̆a çıkartarak öğrencilerle birlikte dersi yapılandırmaktır. Bu doğrultuda planı yetiştirmenin zor olabileceğini düşünmüş olup otoriter yaklaşımları kullandığını belirtmiştir. Bir öğretmen adayı da diyalojik yaklaşımları bilmediği için otoriter yaklaşımları kullandığına değinmiştir.

Öğretmen adayları eğitim sonrasında ise, diyalojik etkileşimli iletişimsel yaklaşımı derslerinde sıklıkla kullandıklarını belirmişlerdir ve diyalojik etkileşimleri kullanabilmelerindeki gerekçeleri belirtmişlerdir. Bir öğretmen adayı, dersinde diyalojik etkileşimli iletişimsel yaklaşımı kullanabilmesinde, öğrenci düşünceleri üzerinden diyaloglarla dersi yapılandırmalarına bağlamıştır. Kouffeta-Menicou ve Scaife (2000) göre, dersler diyaloglar yoluyla yapılandırıldığı zaman öğretmenler çok fazla açık uçlu sorular sorarak öğrencilerin aktif sorgulamasına olanak sağlamaktadır. Yine Erdogan ve Campell (2008) göre, bu yaklaşımla bir dizi öğrencinin görüşü alınır ve öğretmenler açıklama, detaylandırma veya alternatif fikirler aramak, düşünme ve mantık yürütmeyi sağlamak için sorgulamayı kullanır. Bu yolla konuşma kümülatif bir hal alır ve öğrencilerin kollektif olarak fikirleri anlamlandırmalarına, fikirler arasındaki bağlantıları belirlemelerine ve anlamları açıklamalarına destek olunur. 
Bir öğretmen adayı, öğrencilerin cevaplarının detaylandırılmasında öğretmenin öğrenciyi dinlemekteki sabrının çok önemli olduğuna dikkat çekmiştir. Alan-yazın incelendiğinde, Akpınar ve Ergin (2005) sınıf içerisinde öğrenciler soru sorduğunda öğretmenin veya soru sorduğu arkadaşının hemen cevap vermemesi ve belirli bir süre beklemesi gerektiğini belirtmektedirler. Bu sayede bekleme zamanına dikkat edildiğinde, sınıfın çoğunun derse katılması, soru sorması, birbirlerini dinlemesi zihinsel olarak aktif olması gibi olumlu davranışların gelişmesine katkı sağlanacaktır. Ayrıca sınıf içinde düşündüklerini ifade eden bir öğrencinin, öğretmeni tarafından dikkatlice dinlenmesi ve sınıfça söylediklerine değer verilmesi, o öğrencinin kendine olan güvenini artıracağından bu tür davranışların oldukça önemli olduğu vurgulanmıştır. Yine aynı öğretmen adayı, diyalojik etkileşimi dersinde sıklıkla kullanmasındaki gerekçe olarak; öğrencilerin verdiği doğru cevaba değil, öğrencinin verdiği yanlış cevaplara odaklanmasına ve dersini yanlış cevaplar üzerinden devam ettirip, öğrencileri doğru bilgiye ulaştırmasına bağlamıştır.

Araştırmadan elde edilen sonuçlar doğrultusunda, araştırmacılara birtakım önerilerde bulunulmuştur:

- Çalışmadaki veri toplama araçlarından elde edilen veriler, çalışmanın kapsamı doğrultusunda, çalışmanın amacına uygun olarak analiz edilmiştir. Söylem analizi yoluyla, öğretmen adaylarının ve öğretmenlerin sınıflarda sordukları soru tipleri, bu soruları öğrencilerin anlama düzeyleri, öğretmenlerin soruyu sorduktan sonra öğrenci cevapları açısından oluşturdukları bekleme zamanları, öğretmen ve öğrencilerin kavram yanılgıları gibi konulara ilişkin araştırmalar yapılabilir.

- Fen derslerinde öğretmenlerin kullanmış oldukları iletişimsel yaklaşımın öğrencilerin öğrenmeleri üzerindeki etkisine $1 s ̧ 1 \mathrm{k}$ tutacak çalışmalar yapılabilir.

- Öğrencilerin, öğretmenlerin sınıf ortamındaki kullanmış oldukları iletişimsel yaklaşıma ilişkin görüşlerinin araştırıldı ̆̆ı çalışmalar yapılabilir.

\section{Teșekkür ve Bilgilendirme}

$\mathrm{Bu}$ araştırma, Pamukkale Üniversitesi Eğitim Bilimleri Enstitüsü’nde Prof. Dr. Hüseyin Bağ danışmanlığında tamamlanan doktora tez çalışması kapsamında yapılmıştır. Aynı zamanda ilgili araştırma, Pamukkale Üniversitesi Bilimsel Araştırma Projelerince (Proje No: 2013 EĞBE 005) desteklenmiştir. 


\section{References}

Akış, A. (2012). Otoriter ve diyalojik öğretmenlerin öğretmen-öğrenci rollerine dair beklenti ve inançları [Authoritarian and dialogical teachers' expectations and beliefs about their own and students' roles]. Master Dissertation, Gaziantep Üniversity, Gaziantep, Turkey.

Akpınar, E. \& Ergin, Ö. (2005). Yapılandırmacı kuramda fen öğretmeninin rolü [The role of science teacher in constructivist approach]. Elementary Education Online, 4 (2), 54-65.

Alexander, R. (2006). Towards dialogic teaching (3 th Ed), York: Dialogos.

Baş, T. \& Akturan, U. (2008). Nitel araştırma yöntemleri. NVivo 7.0 ile nitel veri analizi. (1.bs) [Qualitative research methods. Qualitative data analysis with NVivo 7.0 (1th ed.)]. Ankara: Seçkin Academy Publishing.

Chin, C. (2006). Classroom interaction in science: Teacher questioning and feedback to students' responses. International Journal of Science Education, 28 (11), 1315-1346.

Demirbağ, M. (2017). Otoriter ve diyalojik söylem tiplerinin fen bilgisi öğretmen adaylarının argüman gelişimine etkisi [The effects of authoritative and dialogic discourses on pre-service science teachers' argument development]. Uludă̆ Üniversity Education Faculty Journal, 30 (1), 321-340.

Erdogan, I. \& Campbell, T. (2008). Teacher questioning and interaction patterns. International Journal of Science Education, 30 (14), 1891-1914.

Game, A. \& Metcalfe, A. (2009). Dialogue and team teaching. Higher Education Research \& Development, 28 (1), 45-57.

Hackling, M., Smith, P., \& Murcia, K. (2010). Talking science: Developing a discourse of inquiry. Teaching Science, 56 (1), 17-22.

Hardman, F. \& Abd-Kadir, J. (2010). Classroom discourse: Towards a dialogic pedagogy. In D. Wyse, R. Andrews \& J. Hoffman (eds.). The International Handbook of English, Language and Literacy, pp. 254-264) Routledge, Taylor and Francis, London.

Kanadlı, S. (2012). Öğretmenlere yönelik hazırlanan bir mesleki gelişim programının etkililiğinin incelenmesi [Investigating the effectiveness of a professional development programme designed for teachers]. Doctorate Dissertation, Gaziantep University, Gaziantep, Turkey.

Kanadlı, S. \& Sağlam, Y. (2012). Öğretmenlerin öğretmen-öğrenci rollerine yönelik inançlarının otoriter ve diyalojik söylevlere etkisi [The influence of teachers' beliefs towards teacher-student roles on authoritarian and dialogical statements]. In Proceedings of the 10th National Science and Math Congress 27-30 June 2012. Niğde University, Niğde, Turkey.

Kanadlı, S \& Sağlam, Y. (2016). Investigating the Effectiveness of a Professional Development Program Designed to Improve Science Teachers' Classroom Discourse. International Online Journal of Educational Sciences, 8 (3), 97-112.

Kaya, G., Şardağ, M., Çakmakçı, G., Doğan, N. İrez, S.\& Yalaki, Y. (2016). Bilimin doğası öğretiminde kullanılan söylem desenleri ve iletişim yaklaşımları [Discourse patterns and communication approaches used in teaching nature of science]. Education and Science, 185 (41), 83-99.

Koufetta-Menicou, C. \& Scaife, J. (2000). Teachers' questions-types and significance in science education. School Science Review, 81 (296), 79-84.

Lehesvuori, S. (2013). Towards dialogic teaching in science: Challenging classroom realities through teacher education. University of Jyväskylä, Jyväskylä.

Lehesvuori, S., Ratinen, I., Kulhomaki, O., Lappi, J. \& Viiri, J. (2011). Enriching primary student teachers' conceptions about science teaching: Toward dialogic inquiry-based teaching. Nordic Studies in Science Education, 7 (2), 140-159. 
Lehesvuori, S., Viiri, J. \& Puttonen, H.R. (2010). Guiding student teachers towards more dialogic science teaching. In G. Çakmakçı \& M. F. Taşar (Eds.), Contemporary science education research: scientific literacy and social aspects of science (pp. 37-46). Pegem Akademi, Ankara.

Lehesvuori, S., Viiri, J. \& Puttonen, H.R. (2011). Introducing dialogic teaching to science student teachers. Science Teacher Education. 22 (8), 705-727.

Löfgren, R., Schoultz, J., Hultman, G., \& Björklund, L. (2013). Exploratory talk in science education: Inquirybased learning and communicative approach in primary school. Journal of Baltic Science Education, 12 (4), 482-496.

MEB. (2013). [Ministry of National Education]. İlköğretim kurumları fen bilimleri dersi öğretim programı [Science teaching programme]. Education Board, Ankara.

Mercer, N., Dawes, L., Wegerif, R., \& Sams, C. (2004). Reasoning as a scientist: Ways of helping children to use language to learn science. British Educational Research Journal, 30 (3), 367-385.

Mercer N., Dawes, L. \& Staarman, J. K. (2009). Dialogic teaching in the primary science classrooms. Language and Education, 23 (4), 353-369.

Miles, M. B. \& Huberman, A. M. (1994). Qualitative data analysis (2nd ed), CA: Sage, Thousand Oak

Molinaria, L. \& Mamelia, C. (2010). Classroom dialogic discourse. An observational study. Procedia Social and Behavional Sciences, 2, 3857-3860.

Monilari, L., Mameli, C. \& Gnisci, A. (2012). A sequential analysis of classroom discourse in Italian primary schools: The many faces of the IRF pattern. British Journal of Educational Psychology, 83, 414-430.

Mortimer, E. F. \& Scott, P. H. (2000). Analysing discourse in the science classroom. In J. Leach, R. Millar, \& J. Osborne (Eds.). Improving science education: The contribution of research (pp. 126-142). Milton Keynes: Open University Press.

Mortimer, E. F. \& Scott, P. H. (2003). Meaning making in secondary science classrooms. Open University Press, Maidenhead/Philadelphia

Nystrand, M., Gamoran, A., Kachur, R., \& Prendergast, C. (1997). Opening dialogue: Understanding the dynamics of language and learning in the English classroom. Columbia University, New York.

Nystrand, M., Wu, L. L., Gamoran, A., Zeiser, S., \& Long, D.A. (2003). Questions in time: Investigating in the structure and dynamics of unfolding classroom discourse. Discourse Processes, 35 (2), 135-198.

Oliveira, A.W. (2009). Developing elementary teachers' understandings of hedges and personal pronouns in inquiry-based science classroom discourse. Journal of Research in Science Education, 8, 247-269.

Ortmann, L. L. (2015). Disciplinary Literacies in STEM Integration: An Interpretive Study of Discourses within Classroom Communities of Practice. A Disserdation Submitted To The Faculty Of The University of Minnesota.

Özdemir, M. (2010). Nitel veri analizi: Sosyal bilimlerde yöntembilim sorunsalı üzerine bir çalışma [Qualitative data analysis: A study on methodological problems in social sciences]. Eskişehir Osmangazi Üniversity Social Science Journal, 11(1), 323-343.

Pimentel, D. S. \& McNeill, K. L. (2010, March). Discourse in science classrooms: The relationship between teacher perceptions and their practice. Paper presented at the annual meeting of the National Association for Research in Science Teaching, PA, Philadelphia

Pimentel, D.S. \& McNeill, K.L. (2013). Conducting talk in secondary science classrooms: Investigating instruction moves and teachers' beliefs. Science Education, 97 (3), 367-394.

Ryder, J \& Leach, J. (2006). Teaching about the epistemology of science in upper secondary schools: An analysis of teachers' classroom talk. Science Education, 17, 289-315. 
Roth, W. M. (2005). Talking science. Language and learning in science classrooms. MD: Rowman and Littlefield, Lanham.

Scott, P. \& Ametller, J. (2007). Teaching science in a meaningful way: Striking a balance between 'opening up' and 'closing down' classroom talk. School Science Review, 88 (324), 77-83.

Scott, P., Ametller, J. Dawes, L., Staarman, K. J., \& Mercer, N. (2007). An investigation of dialogic teaching in science classrooms. Paper presented at NARST: New Orleans, April.

Scott. P. H, Mortimer, E. F. \& Aguiar. O. G. (2006). The tension between authoritative and dialogic discourse: A fundamental characteristic of meaning making interactions in high school science lessons. Science Education, 90, 605-631.

Uçak, E. (2014). Öğretmen adaylarının fen ögretiminde kullandıkları iletişimsel yaklaşımlar. [Communicative approach types used by pre-service teachers' in science teaching]. Doctorate Dissertation, Pamukkale University, Denizli, Turkey.

van Zee, E. H. \& Minstrell, J. (1997). Using questioning to guide student thinking. The Journal of the Learning Sciences, 6 (2), 229-271.

van Zee, E. H., Iwasyk, M., Kurose, A., Simpson, D., \& Wild, J. (2001). Student and teacher questioning during conversations about science. Journal of Research in Science Teaching, 38, 159-190. 